\title{
La incidencia de la Alianza del Pacífico en la revitalización del turismo en sus países miembros
}

Fernando Neira Orjuela

Universidad Nacional Autónoma de México México 


\title{
La incidencia de la Alianza del Pacífico en la revitalización del turismo en sus países miembros
}

\author{
Fernando Neira Orjuela \\ 1 Universidad Nacional Autónoma de México - México
}

\section{RESUMEN}

El objetivo del presente articulo es analizar la incidencia que ha tenido Alianza del Pacifico (AP) en el sector turístico para los países que la integran: México, Chile, Colombia y Perú, con el de evidenciar si había o no efectos positivos para los países involucrados con el surgimiento de la Alianza del Pacifico (AP). El documento presenta además un análisis descriptivo a partir de datos obtenidos del Banco Mundial (BM) y de la Organización Mundial de Turismo (OMT). Se encontró que con la firma de la Alianza del Pacifico en 2012 se aprecian cambios importantes en la dinámica turística de los países miembros, como es el crecimiento sostenido del turismo en todos los países que conforman la AP.

Palabras clave: Turismo; Chile; México; Perú; Colombia; Alianza del Pacífico.

The impact of the pacific alliance in the activation of tourism in the member countries

Editor: Andrés Escobar E. Universidad de Cartagena-Colombia.

\section{Tipología IBN Publindex:}

Artículo de Reflexión

Copyright: $(\mathrm{C}$ 2021. Neira Orjuela, F. Este es un artículo de acceso abierto, distribuido bajo los términos de la licencia https://creativecommons.org/licenses/bync-sa/4.0/ la cual permite el uso sin restricciones, distribución y reproducción en cualquier medio, siempre y cuando que el original, el autor y la fuente sean acreditados.

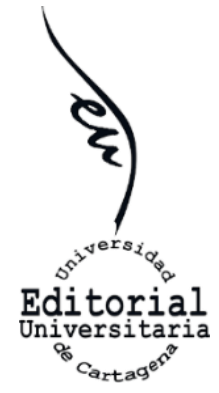

\section{ABSTRACT}

The objective of this article is to analyze the impact that the Pacific Alliance (PA) has had in the tourism sector of the countries that integrate this Alliance: Mexico, Chile, Colombia, and Peru, to show whether there are positive or negative effects for these countries. The document also presents a descriptive analysis of data obtained from the World Bank (WB) and the World Tourism Organization (UNWTO). It was found that with the signing of the Pacific Alliance in 2012, there were important changes in the tourism dynamics of the member countries.

Keywords: Tourism; Chile; Mexico; Peru; Colombia; Pacific Alliance. 


\section{INTRODUCCIÓN}

En un marco de plena globalización y apertura comercial, distintos sectores que explican la evolución de la economía de los países de Latinoamérica han mostrado un crecimiento constante. En este sentido el de servicios, al que pertenece el turismo, ha demostrado ser una importante fuente de generación de divisas y exportación en materias de servicios para países de la región. No es de sorprender entonces que con el surgimiento de la Alianza del Pacífico como un mecanismo de integración regional y económico propuesta por los presidentes de Chile, Colombia, Perú y México, buscando la libre circulación de bienes, servicios, capitales y personas para impulsar el desarrollo y la competitividad entre economías, el turismo tuviese un lugar importante.

En la Alianza del Pacífico, los países Colombia, Chile, México y Perú han mostrado una evolución constante en el sector de servicios, precisamente en lo referente a la oferta y demanda turística. Este hecho ha evidenciado la importancia que tiene y los grandes beneficios que proporciona al objetivo de integración regional planteada al interior de la Alianza. Actualmente, los países socios se enfrentan a diversos retos entre los cuales se encuentra la cuestión de brindar servicios de calidad que respondan a las preferencias y demanda del mercado mundial, no solo para aumentar en particular el consumo turístico interregional y aprovechar las ventajas comparativas, sino para acentuar las ventajas competitivas que poseen los países que integran este acuerdo respecto a otros destinos turísticos.

El presente articulo, tiene como objetivo de analizar la importancia del sector turístico para los países de México, Chile, Colombia y Perú, en el periodo de 2009 a 2017. El documento se encuentra dividido en tres apartados, en un primer momento, se explica el contexto del sector turístico para México, Chile, Colombia y Perú. En un segundo apartado, se presenta un análisis comparativo en un contexto, anterior a la conformación de la Alianza del pacifico. Posteriormente, se extiende el análisis con la entrada en vigor de la Alianza del Pacífico con el fin de evidenciar los efectos en el sector turístico. Finalmente, se presentan las principales conclusiones.

\section{CONTEXTO DEL TURISMO EN LA REGION}

\section{Chile}

En la última década Chile ha experimentado un incremento impresionante en número de turista extranjeros, entre 2015y 2016 la visita de turistas internacionales aumentó un 26\% (Servicio Nacional de Turismo 2017). Aunque no figura dentro de los principales destinos turísticos a nivel mundial, no se puede descartar su importancia en el continente americano. De acuerdo con la Organización Mundial de Turismo (OMT), fue el tercer destino turístico más importante en América del Sur y el sexto destino más importante en América. Por la participación del sector turismo dentro del PIB de Chile, este se considera la sexta industria más importante de la economía, por detrás de la minería (32000 millones de dólares); el sector frutícola (4 500 millones de dólares); la industria química (4 300 millones de dólares); celulosa y papel (3 100 millones de pesos) y del salmón (3 000 millones de dólares) (Díaz 2016). 
En los últimos años, el turismo ha crecido a un ritmo 15 veces mayor que la actividad económica total, la cual ha figurado en un crecimiento de 1.75\%. La consecuencia directa de este crecimiento es la generación de empleos directos e indirectos que la expansión de dicho sector ha generado. Por su parte, la cantidad de divisas obtenidas del turismo corresponde al aumento del número de llegadas de turistas extranjeros y al incremento en la cantidad de días de permanencia en Chile, generando un ingreso de divisas de US\$ 4 mil 200 millones solo en 2017, lo cual indica un crecimiento importante respecto de 2016 (Servicio Nacional de Turismo 2018). El desenfrenado crecimiento del turismo en Chile se ha vinculado a los programas de competitividad y promoción turística de su propio gobierno, tan solo en 2012 Chile invirtió 6 millones de dólares en promoción turística y la cifra incremento a 14 millones de dólares para 2015, y 23 millones de dólares para 2018; es así como Chile se ha convertido en uno de los países con mayor promoción turística y lo ha colocado como un país competitivo en el sector.

A continuación, se muestra detalladamente variables suficientes que justifican el crecimiento exponencial del turismo receptivo en el país andino.

Gráfico 1. Participación del Sector Turismo en el PIB de Chile, 2012-2017

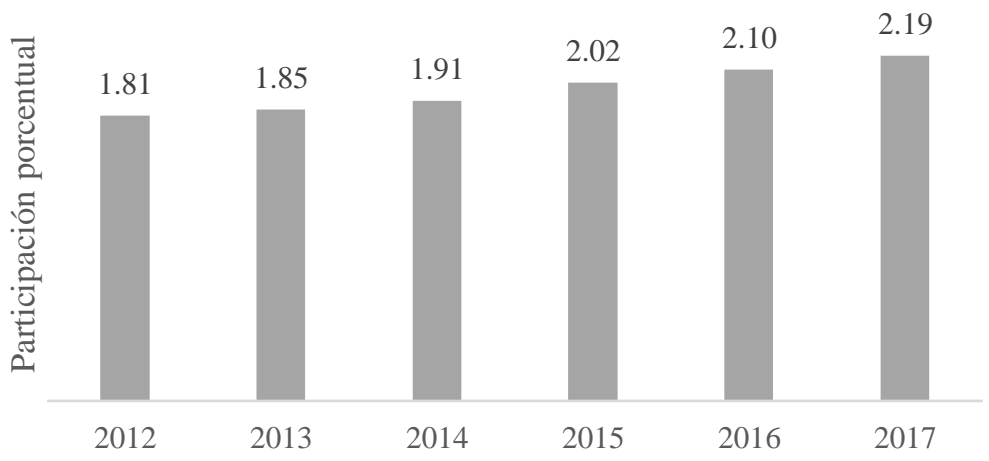

Fuente: Elaboración propia con base en datos de (Banco Central de Chile 2019)

La importancia del turismo dentro del PIB nacional en Chile ha incrementado del $1.81 \%$ al 2.19\%. Esto significa un incremento en términos absolutos de 1598 millones de pesos chilenos. Entre 2012 a 2017, el PIB turístico ha presentado incrementos continuos dentro del PIB nacional, siendo para 2017 el de mayor significación y el de 2012 de menor significancia.

Gráfico 2. Variación (\%) del PIB turístico de Chile, 2012-2017

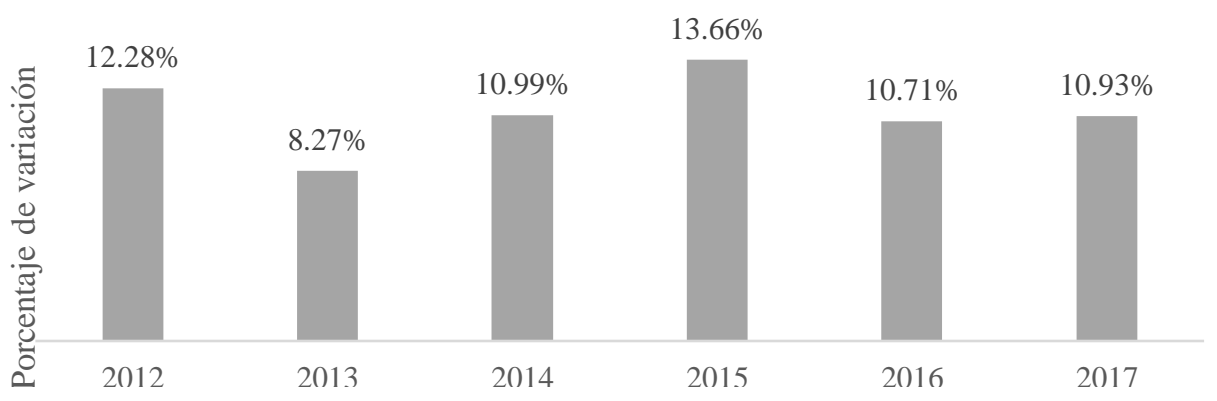

Fuente: Elaboración propia en base a datos del Banco Central (Banco Central de Chile 2019) 
El crecimiento del turismo ha sido positivo y variado, además sus tasas de crecimiento se encuentran muy por encima a las que ha experimentado la economía total; entre 2012 y 2017 el PIB nacional ha variado entre tasas del 6.1\% y 7.4\%; y a una tasa de crecimiento promedio anual de 6.76\%. Por su parte el PIB turístico ha variado entre el $8.27 \%$ como mínimo, y como máximo el 13.66\%; asimismo, su tasa de crecimiento promedio anual de 10.71\%. El mayor incremento se originó entre 2014 y 2015 como resultado de un aumento de 387 millones de pesos chilenos en el turismo.

Gráfico 3. Número de entradas de extranjeros a Chile, 2012-2017

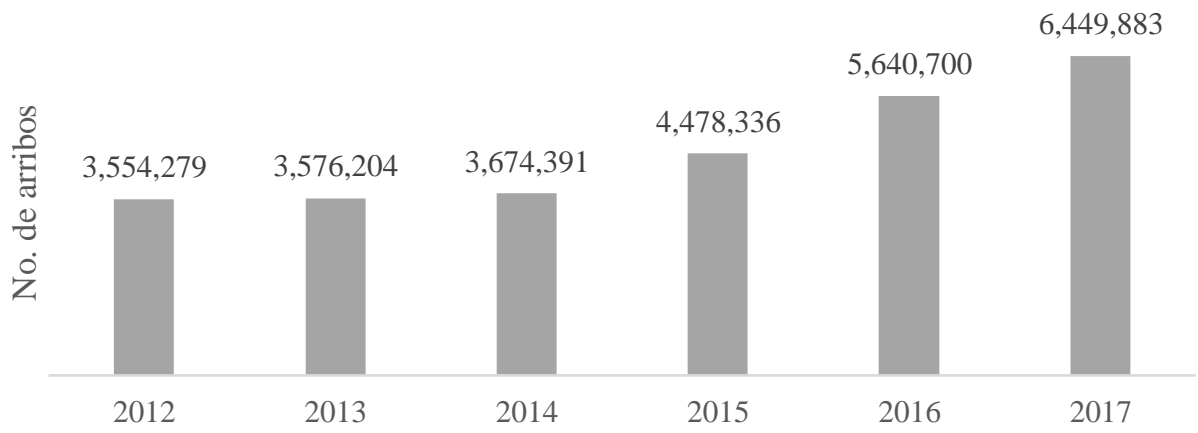

Fuente: Elaboración propia con base en datos Servicio Nacional de Turismo (SERNATUR 2019)

El número de entradas de turistas extranjeros para el caso chileno presenta aumentos continuos, de 2012 a 2017 esta cifra se elevó en 2896604 de visitas lo que se traduce en una tasa de crecimiento de $87.46 \%$. Los años de menor crecimiento se registraron en 2012, 2013 y 2017; por el contrario 2017 represento el año con mayor crecimiento con una tasa de $14.34 \%$ estableciendo un nuevo récord. Este dinamismo turístico ha colocado a Chile como uno de los países con mayor crecimiento en el número de llegadas internacionales. En 2012, Chile recibió casi cuatro millones de turistas. En 2017, la cifra se elevó a cinco millones, según el informe World Travel Market (WTM) Latín América de Euromonitor International. Se trata de un alza de 10,6\%, lo que convierte a Chile en el país que tuvo el mayor crecimiento porcentual de visitas turísticas en la región durante este período.

Gráfico 4. Procedencia de extranjeros a Chile, 2012-2017

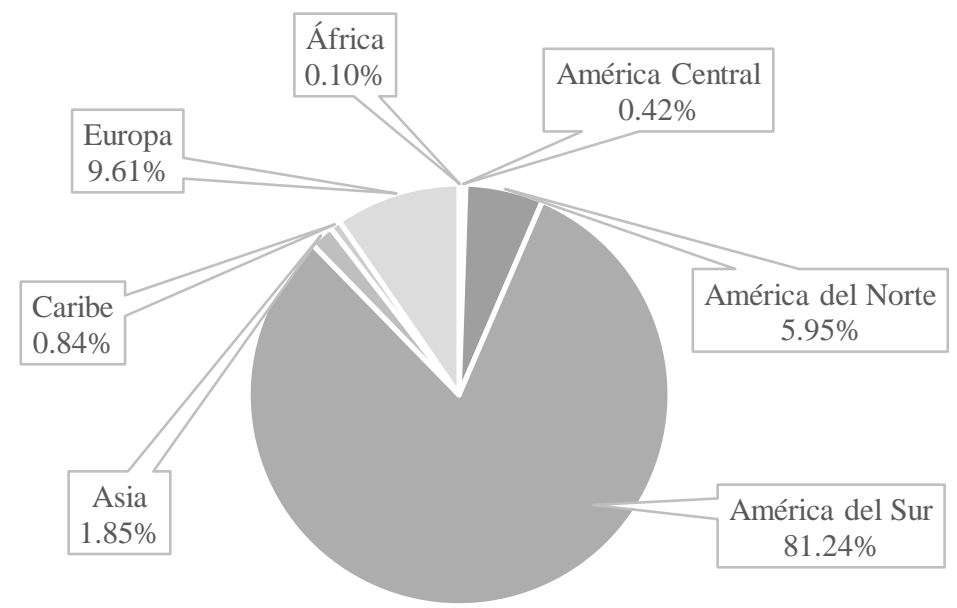

Fuente: Elaboración propia con base en datos de Sernatur (SERNATUR 2019) 
Gráfico 5. Procedencia de extranjeros (América) a Chile, 2012-2017

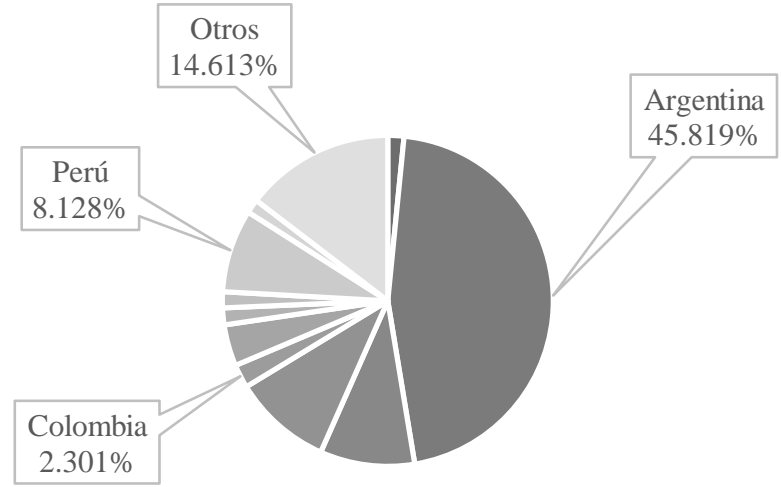

Fuente: Elaboración propia con base en datos de Sernatur (SERNATUR 2019)

De los 27373793 turistas extranjeros que visitaron Chile de 2012 a 2017; la mayoría provenían de América del Sur, representado el 81.24\% de total; la segunda región de mayor procedencia es América del Norte, le sigue Europa con el 9.61\%. Los visitantes más numerosos son los argentinos, puesto que explican el $45.81 \%$ de los turistas totales en Chile; los brasileños, bolivianos y peruanos también representan un porcentaje importante de los turistas con una participación del 8.18\%; 9.67\% y 9.25\%. Por su parte, los principales turistas europeos procedieron de España, Alemania y Francia; estos contribuyeron 441 005; 420384 y 418591 de turistas. Finalmente 1082017 de los turistas provinieron de Estados Unidos representando el $4.01 \%$ del total.

Gráfico 6. Divisas provenientes del turismo en Chile, 2012-2017

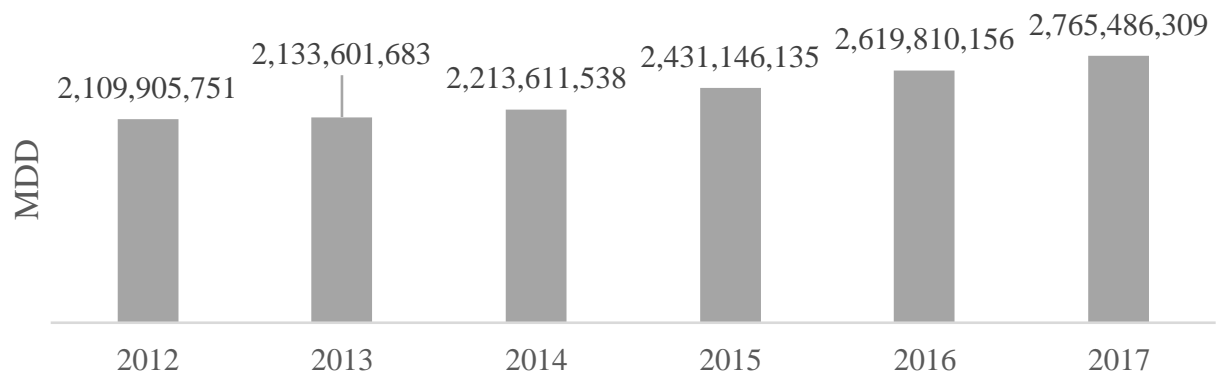

Fuente: Elaboración propia con base en datos de Servicio Nacional de Turismo (SERNATUR 2019)

Chile no figura dentro de los países con mayor ingreso por turismo internacional; a pesar de esto su posicionamiento a nivel mundial ha mejorado, de acuerdo con la Organización Mundial de Turismo (OMT) en el 2010, Chile se posiciono en el lugar 135 por divisas obtenidas del turismo, para 2017 avanzó a la posición 109 (World Tourism Organization 2018 ). Los ingresos de divisas por turismo internacional siguen siendo significativas, esto ha colocado a la industria en el cuarto lugar en exportación de bienes, y el primer lugar en exportación de servicios. Las divisas por turismo internacional de 2012 a 2017 crecieron en 655580 millones de dólares, traducido en una tasa de crecimiento anual de 5.6\%. 
Gráfico 7. Composición del gasto total del turismo en Chile, 2012-2017

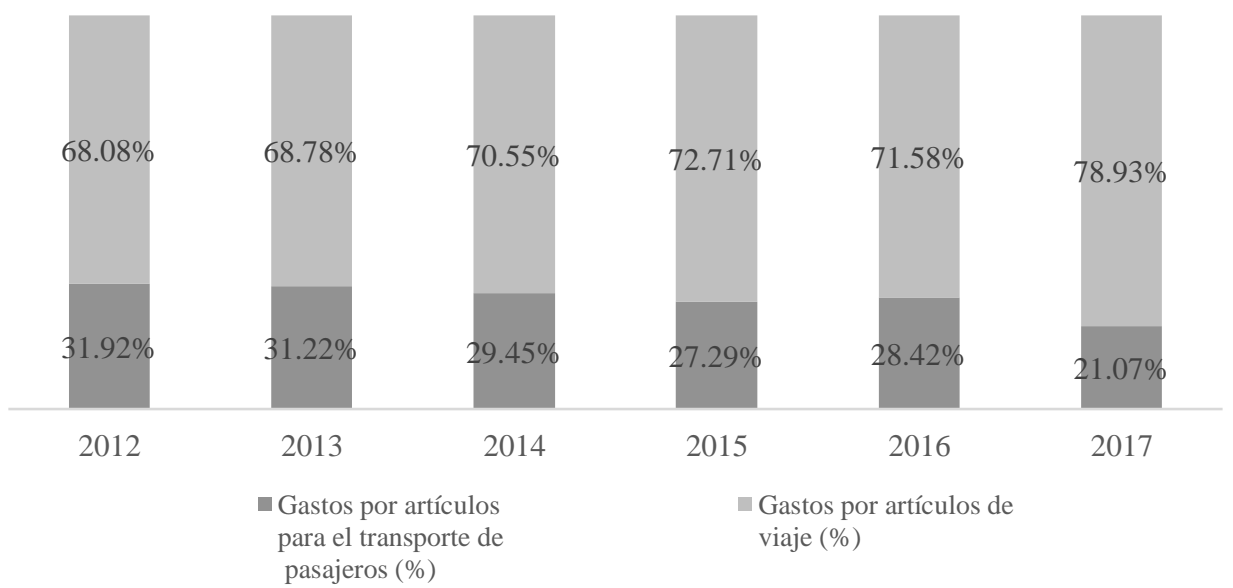

Fuente: Elaboración propia con base en datos de Banco Mundial (WBG 2019)

En el Gráfico 7 podemos observar la composición del gasto total; en este sentido, el gasto de los artículos para el transporte de pasajeros conforma entre el $21.07 \%$ y $31.92 \%$ del gasto total, este porcentaje es elevado; no obstante, ha disminuido 10 puntos porcentuales. El gasto en artículos de viaje represento entre el $68.08 \%$ y $78.93 \%$ del gasto, esto significa que mostro un incremento en el gasto total en respuesta a la disminución del gasto en artículos para el transporte de pasajeros.

Tabla 1. Gastos totales y gastos personales de turismo internacional en Chile en millones de dólares, 2012-2017

\begin{tabular}{|c|c|c|c|c|c|c|}
\hline & 2012 & 2013 & 2014 & 2015 & 2016 & 2017 \\
\hline Gastos totales $(\mathrm{A})$ & $\begin{array}{c}\$ 3,158,000,00 \\
0\end{array}$ & $\$ 3,171,000,000$ & $\begin{array}{c}\$ 3,202,000,00 \\
0\end{array}$ & $\begin{array}{c}\$ 3,412,000,00 \\
0\end{array}$ & $\begin{array}{c}\$ 3,723,000,00 \\
0\end{array}$ & $\$ 4,604,000,000$ \\
\hline $\begin{array}{l}\text { Entradas de } \\
\text { extranjeros (B) }\end{array}$ & $\$ 3,554,279$ & $\$ 3,576,204$ & $\$ 3,674,391$ & $\$ 4,478,336$ & $\$ 5,640,700$ & $\$ 6,449,883$ \\
\hline $\begin{array}{l}\text { Gastos } \\
\text { personale } \\
\mathrm{s}(\mathrm{A} / \mathrm{B})\end{array}$ & $\$ 888.51$ & $\$ 886.69$ & $\$ 871.44$ & $\$ 761.89$ & $\$ 660.02$ & $\$ 713.81$ \\
\hline
\end{tabular}

Fuente: Elaboración propia con base en datos de Banco Mundial (WBG 2019)

Los gastos totales por turismo internacional aumentaron 69\% al mismo tiempo el número de entradas de extranjeros aumento 81\%; no obstante, el gasto personal de los turistas presenta variaciones negativas, puesto que se estancó entre 2012 y 2014; mientras que en 2016 y 2017 disminuyó 283.49 dólares y 174.7 dólares respecto al 2012. El año de 2017 suele ser remarcado como el de récord para el turismo chileno; sin embargo, este éxito está enmarcado en gran medida por el menor dinamismo que se experimentó un año anterior. Tal y como se observa en la tabla 2.1 el gasto personal aumento de 2016 a 2017; esta cifra estuvo acompañada del impresionante incremento de los turistas y del incremento de días de estadías por parte de los visitantes. Según detalla el sitio Emol, el año 2017 aumentó la llegada de turistas extranjeros y, con ello también se incrementó el nivel de gasto que estuvo marcado por el alza de la permanencia promedio que fue de 10 noches, 2,5 más que el año anterior (Albertini 2018). En otras palabras, se debe trabajar más para incrementar el gasto personal de los turistas de tal manera que este sujeto al dinamismo que presenta el incremento en el número de turistas internacionales. 


\section{Colombia}

El turismo en Colombia representa una gran derrama económica esto se refleja por su participación dentro del PIB nacional; con una participación del 3\% aproximadamente, rebasa el porcentaje promedio mundial; asimismo, el PIB turístico en este país ha crecido considerablemente; con una variación en 2017 de cerca del 10\% se encuentra siete puntos porcentuales por encima del crecimiento mundial en dicho sector. En 2018 el crecimiento en turismo fue menor, pero no despreciable: En 2018, la contribución del turismo al Producto Interno Bruto (PIB) de Colombia fue de un 3,8 por ciento mientras que el crecimiento de la economía fue de 2,7 por ciento (Pinto Molinares 2019). Este sector ha crecido sustancialmente, en 2012 fue la tercera actividad más importante dentro de la generación de divisas y exportaciones; cinco años después se convirtió en el segundo generador de divisas del país, después del sector minero-energético (Santoro 2019).

Además, es uno de los sectores de mayor arrastre de acuerdo con el boletín de Ministerio de Comercio y de Migración Colombia el empleo, el comercio, los hoteles y los restaurantes generan 6107435 empleos directos e indirectos equivalente al 26.7\% del total de 2017. En las cifras se incluyen agencias de viajes, alojamiento, transporte aéreo y terrestre de pasajeros, alimentos, bebidas y esparcimiento. Colombia no figura como los principales destinos mundiales por parte de los turistas extranjeros; no obstante, tiene un importante papel a nivel regional; así, por ejemplo, en 2010 fue el sexagésimo primer país más visitado del mundo, el octavo en el continente americano y el segundo en América del Sur, encontrándose por detrás de Estados Unidos, México, Canadá, Martinica, Costa Rica, República Dominicana y Perú. Para el mismo año Colombia se ubicó en el septuagésimo séptimo país a nivel mundial, sexto en América y tercero en América Latina por concepto de ingresos por turistas extranjeros; siendo rebasado para los dos últimos casos por Estados Unidos, Canadá, México, Brasil y Argentina.

Gráfico 8. Participación (\%) del PIB turístico como porcentaje del PIB total en Colombia, 2012-2017

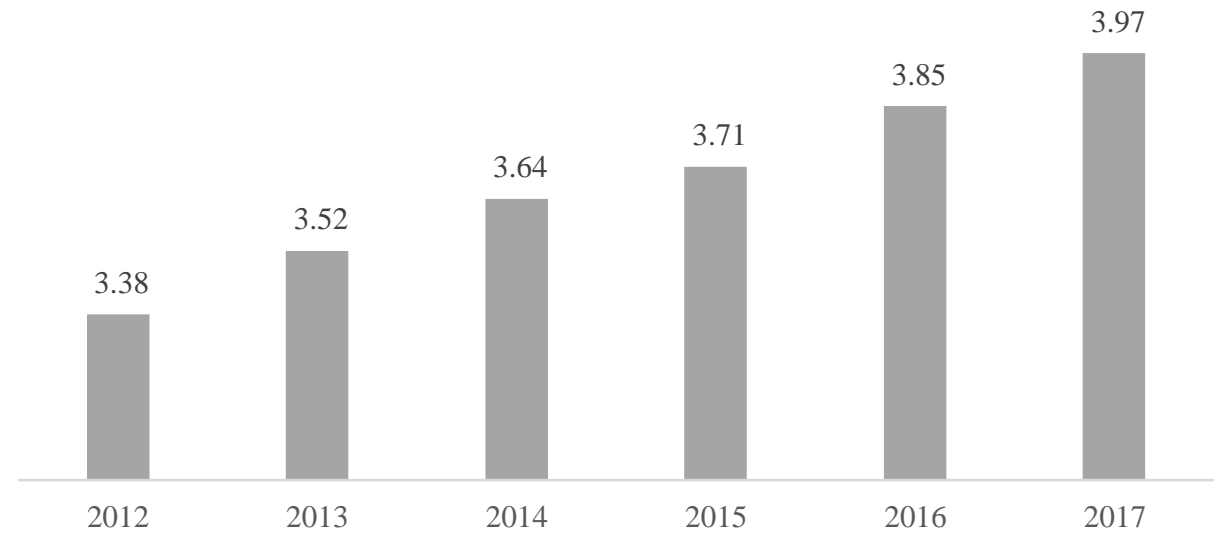

Fuente: Elaboración propia con base en datos del Departamento Administrativo Nacional de Estadístico (DANE 2019)

Entre 2012 y 2017 la participación del PIB turístico ha presentado contante crecimiento, a inicio del periodo su participación era del 3.38\%; para 2017 este porcentaje aumento a $3.97 \%$, significando un aumento de 0.59 puntos porcentuales y una tasa de incremento promedio anual de $0.032 \%$. 
Gráfico 9. Variación (\%) del PIB turístico de Colombia, 2012-2017

13.80

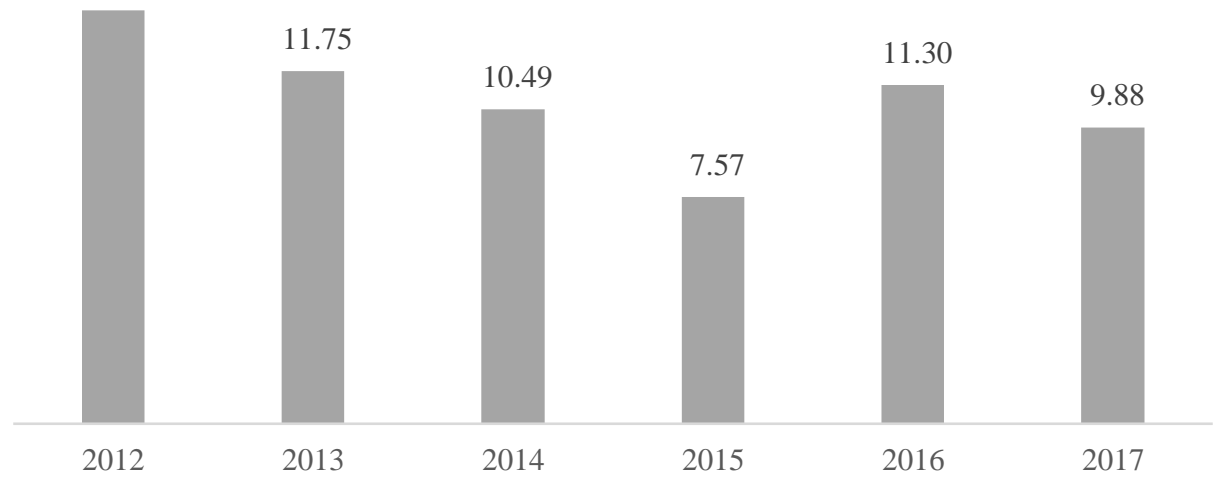

Fuente: Elaboración propia con base en datos del Departamento Administrativo Nacional de Estadístico (DANE 2019)

El crecimiento del PIB turístico se puede reflejar a través de las variaciones entre un año y el otro. En este sentido podemos observar que el PIB turístico en Colombia ha tenido un crecimiento volátil; sin embargo, este nunca representa números negativos. El año donde se experimentó mayor crecimiento es en 2012 con una tasa del 13.80\%; entre 2012 y 2015 el crecimiento disminuyó 6.23 puntos porcentuales. En 2016 se recupera la tasa de crecimiento y finalmente en 2017 vuelve a caer. Del gráfico 9 podemos decir que este crecimiento es muy cambiante, pero esto no se define como fracaso; sino por el contrario, al presentar tasa de crecimiento positivas cercanas al 10\% se puede decir que esta actividad es sumamente dinámica e importante en la economía colombiana. Según datos del Centro de Información Turística de Colombia, con base en el DANE, la cuenta de hoteles y restaurantes ha tenido un crecimiento de 24\% en los últimos seis años, 6,9\% por encima del promedio nacional, según los datos a cierre de 2017. (Portafolio 2018)

Gráfico 10. Número de entrada de extranjeros a Colombia, 2012-2017

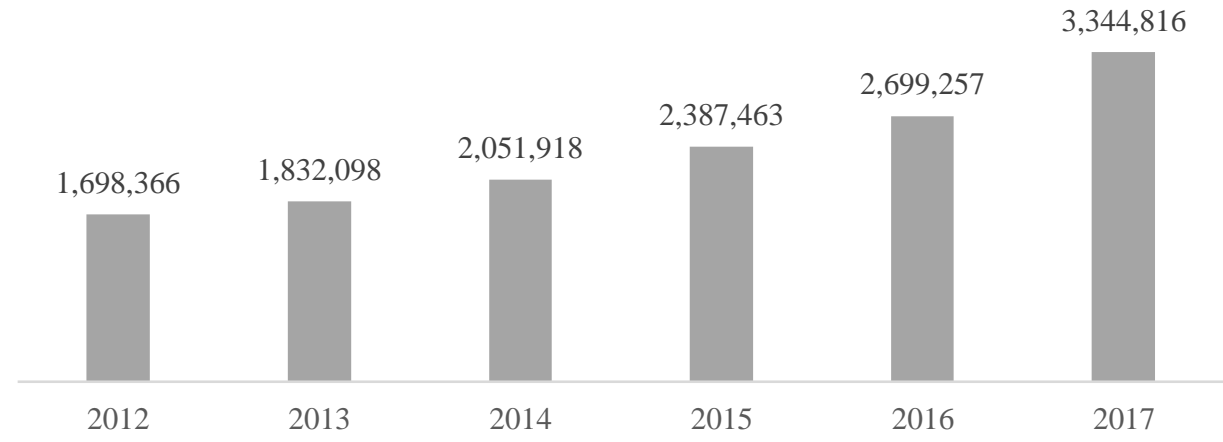

Fuente: Elaboración propia con base en datos de Centro de Información Turística de Colombia (CITUR 2019)

De 2012 a 2017, Colombia presento un aumento de 1698266 turistas extranjeros, lo que se traduce en una tasa promedio anual del 14.51\%. En 2010 Colombia se ubicaba en el sexagésimo primer lugar de los países más visitados en el mundo; siete años después 
avanzó a la trigésima cuarta posición (World Tourism Organization 2018 ). El amplio crecimiento en el número de entradas de extranjeros en Colombia ha colocado a este país entre los países más visitados de América del Sur. El MinCIT recalcó que "El bueno momento del turismo" en el país andino se hace más evidente si se comparan las cifras de comienzo de década: entre 2010 y 2017, el crecimiento de visitantes extranjeros fue de 150\% (Carranza Jimenez 2018)

Gráfico 11. Procedencia de extranjeros a Colombia, 2012-2017

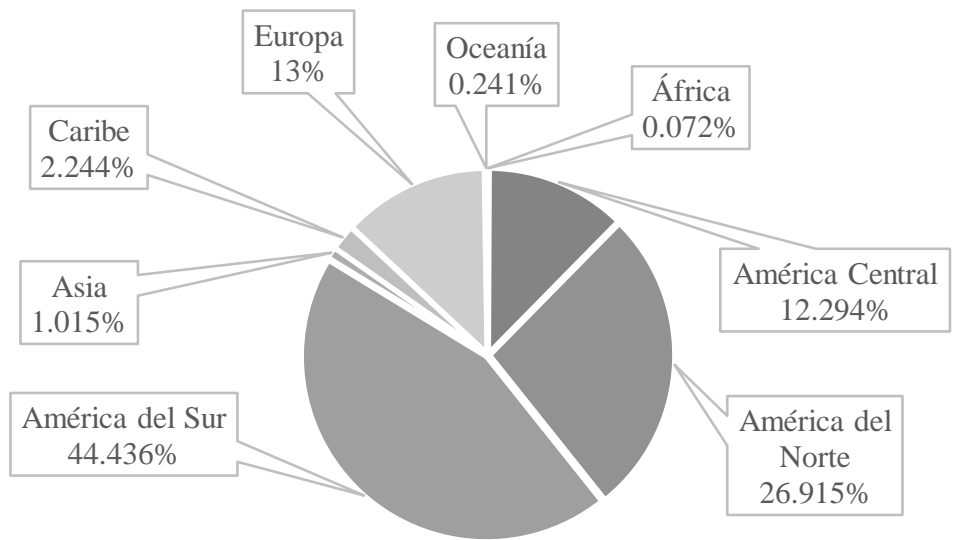

Fuente: Elaboración propia con base en datos de Centro de Información Turística de Colombia (CITUR 2019)

Gráfico 12 Porcentaje de arribos a Colombia provenientes de los países de la AP 2012-2017

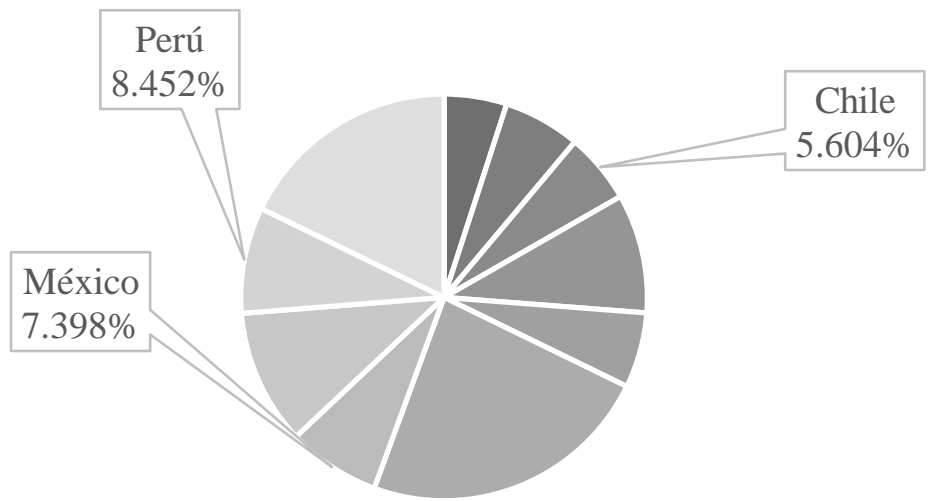

Fuente: Elaboración propia con base en datos de Centro de Información Turística de Colombia (CITUR 2019)

De los 14013918 turistas extranjeros que visitaron Colombia entre 2012 y 2017; el 7500 918 eran provenientes de la región de América del Norte y América del Sur, sumando el $76.351 \%$ del total; le siguen en tercer y cuarto lugar los turistas que provienen de Europa y América Central; los turistas que provienen de África sumaron un total de 10 067, obteniendo una participación de menos del 1.00\%. En el gráfico 12 quisimos resaltar la participación del arribo de turistas que provienen de los países ahora miembros de la AP, 
en este sentido es observable que los turistas peruanos se dirigen en mayor medida a Colombia, seguidos por turistas de nacionalidad mexicana y Chilena.

Gráfico 13. Divisas provenientes del turismo a Colombia, 2012-2017

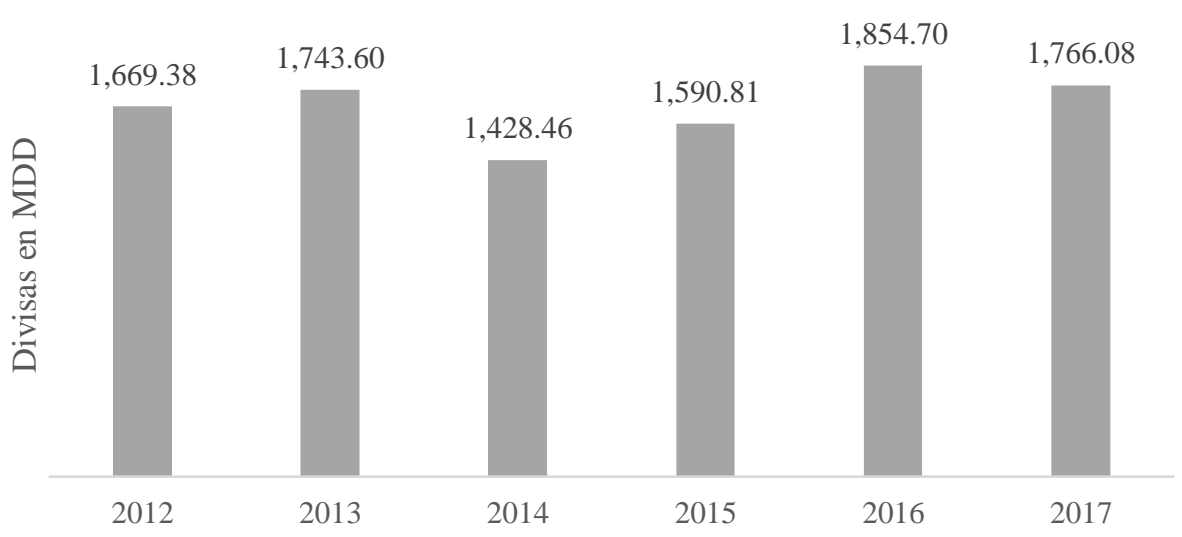

Fuente: Elaboración propia con información de Servicio Nacional de Turismo (SERNATUR 2019)

De acuerdo con el ranking de los países con mayor ingreso de divisas por turismo del barómetro 2018 de Turismo de la World Tourism Organization, Colombia ocupa el octagésimo séptimo país a nivel mundial, el treceavo en el continente americano y el cuarto en América Latina; respecto a 2016 representó un retroceso de cuatro lugares. Como se puede observar en la gráfica 2.6; los ingresos por turismos en Colombia se han mantenido más o menos en el mismo nivel; lo que significa que el incremento sustancial de turistas extranjeros no se traduzco en un aumento en los gastos o permanencia de esto; así, por ejemplo, 2017 fue el año récord por número de turistas extranjeros; no obstante, las divisas disminuyeron 88.7 millones de dólares.

Referente a la composición del gasto por turismo los gastos por artículos de viaje se mantienen representando el mayor porcentaje del gasto efectuado por turistas, sin embargo como observamos en el siguiente gráfico el gasto por artículos para el transporte de pasajeros han disminuido ya que a inicio de periodo este representaba el $20.7 \%$ y al final este significo 16.57\%; por otro lado, este desplazamiento se tradujo en el aumento en los gastos por artículos de viaje; de tal manera que para 2017 el $83.43 \%$ del gasto total se explica por los gastos por artículos de viaje

Gráfico 14. Composición total de los gastos por turismo en Colombia, 2012-2017

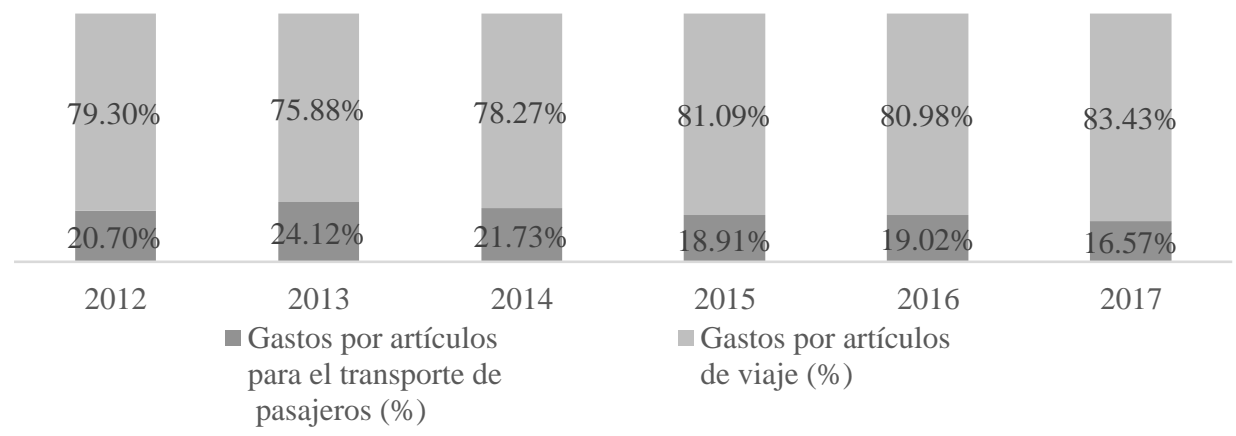

Fuente: Elaboración propia con base en datos del Banco Mundial (The World Bank Group 2019) 
Seguido, al referirnos a los gastos personal por turista mediante la tabla 2 se observan cambios en los gastos totales y gastos personales por turismo internacional; a pesar del aumento de 14380000000 millones de dólares en el gasto total, los gastos personales de 2012 a 2017 disminuyeron 834.65 dólares por turista, esta disminución es equivalente a una tasa negativa del 32.48\%; en otras palabras: el decremento de los gastos personales por tasa promedio anual ha sido del $7.55 \%$. De esto se pueden concluir dos cosas: por una parte, el incremento de los gastos totales ha sido menos acelerado respecto a la rápida aceleración de la entrada de turistas extranjeros. La tasa de crecimiento de los gastos totales entre 2012 y 2017 fue de 32.9\%, mientras que el crecimiento de turistas extranjeros fue de $96.94 \%$; y por otro lado, el incremento en la entrada de extranjeros no ha garantizado el aumento en sus gastos personales, sino por el contrario se ha experimentado una continua desaceleración en sus gastos personales.

Tabla 2. Gastos totales y gastos personales de turismo en Colombia en millones de dólares

\begin{tabular}{lcccccc}
\hline & 2012 & 2013 & 2014 & 2015 & 2016 & 2017 \\
\hline Gastos totales (A) & $4,363,000,000$ & $4,759,000,000$ & $4,887,000,000$ & $5,235,000,000$ & $5,584,000,000$ & $5,801,000,000$ \\
$\begin{array}{l}\text { Entradas de } \\
\text { extranjeros (B) }\end{array}$ & $1,698,366$ & $1,832,098$ & $2,051,918$ & $2,387,463$ & $2,699,257$ & $3,344,816$ \\
$\begin{array}{l}\text { Gastos } \\
\text { personales (A/B) }\end{array}$ & $2,568.94$ & $2,597.57$ & $2,381.67$ & $2,192.70$ & $2,068.72$ & $1,734.33$ \\
\hline
\end{tabular}

Fuente: Elaboración propia con base en datos de Banco Mundial (WBG 2019)

\section{México}

El turismo en México genera cerca del 9\% del PIB total, este sector es el tercer receptor de divisas después de los ingresos petroleros y de las remesas (Reuters 2013 ), además genera 8.5 millones de empleos directos e indirectos, representando el 17\% del total de los trabajos en el país, en este sentido es una de las actividades económicas mas importantes de México. Por su oferta en productos y destinos turísticos México se encuentra entre los diez principales destinos turísticos a nivel mundial en consecuencia es uno de los países con mayor cantidad de llegadas de extranjeros.

Pese al bajo crecimiento nacional del $0.5 \%$, se espera que el turismo registre un crecimiento mayor a la de la economía completa. Se estima que en los próximos diez años la actividad turística en México experimente un crecimiento anual de 2.9\% este valor supera al incremento que se espera en sectores como la minería, agricultura, construcción y comercio al por menor. Las estadísticas se han mantenido aun cuando los retos del sector fueron (son y serán) los mismos: promoción del país en el extranjero (Espinoza 2019). No obstante, el crecimiento del sector no es algo nuevo, más bien es algo que se ha ido acelerando con los años. Éste ha crecido entre 1977 y 2016 77.3\%, mientras que la economía total ha aumentado sólo 58.5\%. (Parcerisa 2017).

Así es que se trata por lo menos del tercer sector más importante de la economía mexicana, de un total de ocho que incluye a la agricultura, la minería, la manufactura química, la manufactura automotriz, el comercio al menudeo, los servicios financieros en su conjunto, la banca por separado, además de la construcción. (Excelsior 2016 ). Esto solo menciona un conjunto de cifras relevantes que muestran que la actividad turística en México es sumamente importante para el desarrollo económico del país y que además tiene la capacidad de competir con países mas desarrollados. Con el objetivo de mostrar 
el dinamismo del sector a continuación se muestran los principales indicadores de turismo como el PIB sectorial, número de llegadas, composición de llegadas según región y nacionalidad, variación anual, generación de divisas, exportaciones, gasto total y gasto personal.

Gráfico 15. PIB turístico como porcentaje del PIB total en México, 2012-2017

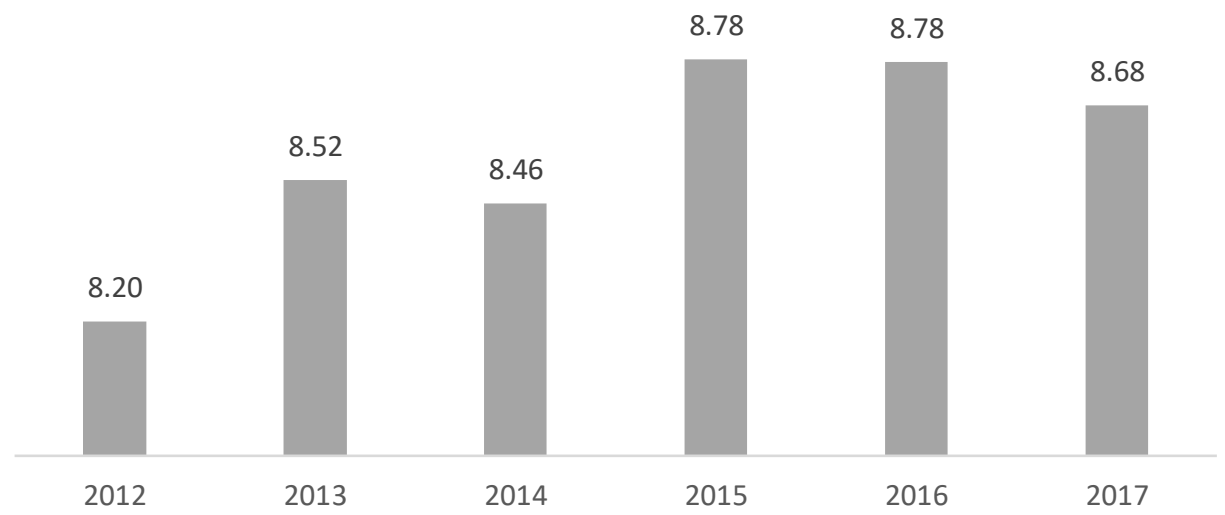

Fuente: Elaboración propia con base en datos del Instituto Nacional de Estadística y Geografía (INEGI 2019)

La importancia del turismo en México se puede apreciar en su aportación dentro del PIB nacional, de 2012 al 2017 el PIB turístico en México tuvo una participación del 8.2\% al 8.78\% dentro del PIB total; 2012 es el año con menor participación representando solo el 8.2\%; mientras que 2015 y 2016 son los años donde el turismo aportó mayor proporción en el PIB total.

Gráfico 16. Variación(\%) del PIB turístico en México, 2012-2017

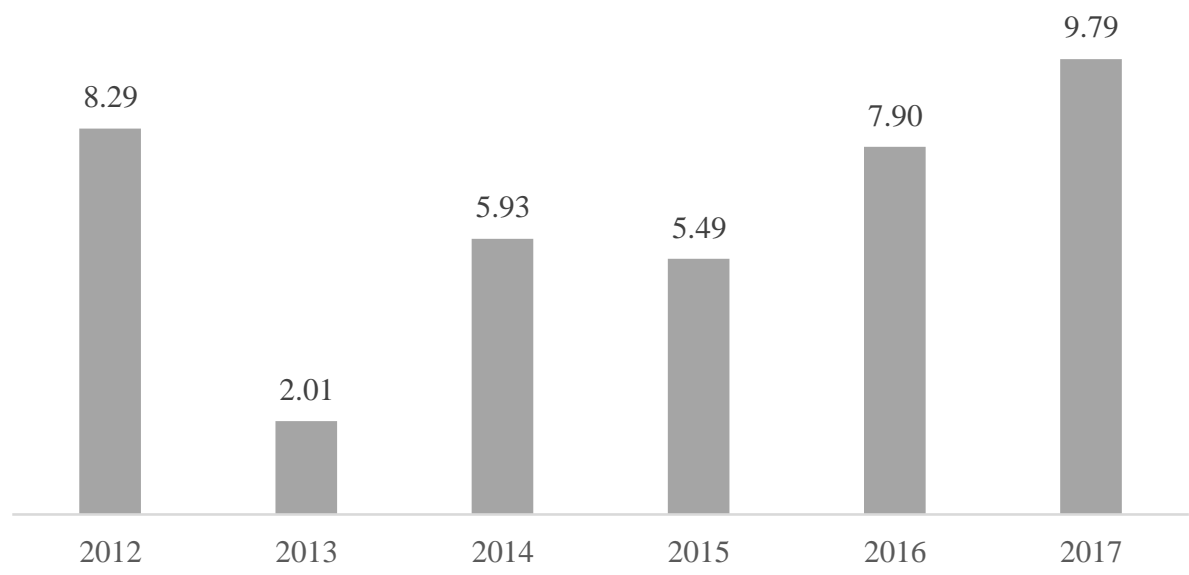

Fuente: Elaboración propia con base en datos del Instituto Nacional de Estadística y Geografía (INEGI 2019)

El gráfico 16 muestra la variación del PIB turístico, esto también representa el crecimiento del sector. 2017 representa el año donde el turismo tuvo más crecimiento, en términos absolutos el PIB turístico de 2016 a 2017 aumentó 1845815 millones de pesos mexicanos; 
por otro lado, 2011 es el año con menor crecimiento con una variación del 2.01\%. Para el resto de los años el PIB sectorial vario entre el 5.49\% y $8.29 \%$.

Gráfico 17. Número de arribos a México, 2012-2017

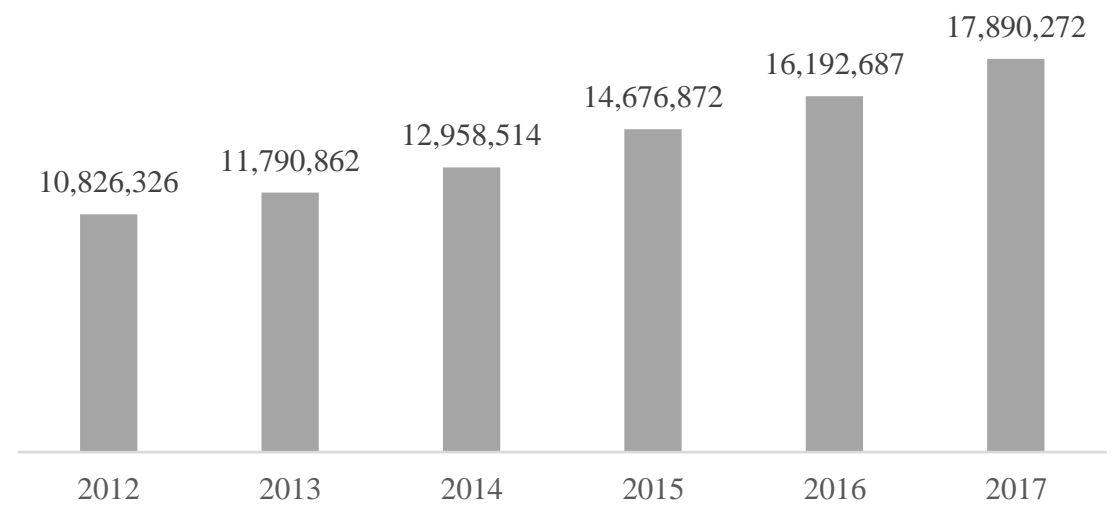

Fuente: Elaboración propia con base en datos de Secretaria de Gobernación (SEGOB 2019)

De acuerdo con los datos de la Organización Mundial de Turismo (OMT) en la última década México ha figurado dentro de los 15 países más visitados por extranjeros, en 2017 se ubicó en el sexto lugar dentro del ranking de los 18 países más visitados del Barómetro OMT; solo fue rebasado por Francia, España, Estados Unidos, China e Italia. El número de turistas internacionales que nuestro país recibió de 2012 a 2016 creció en más del 50\% (Pantoja 2019). El incremento en el número de entradas de extranjeros ha sido constante, entre 2012 y 2017 el número de turistas extranjeros aumento 7063 946, a su vez corresponde a una tasa de crecimiento promedio anual de 10.57\%. En este sentido mediante las siguientes gráficas mostramos la composición del turismo por nacionalidad dirigido a México. 
Gráfico 18. Arribos de turismo extranjero a México, 2012-2017

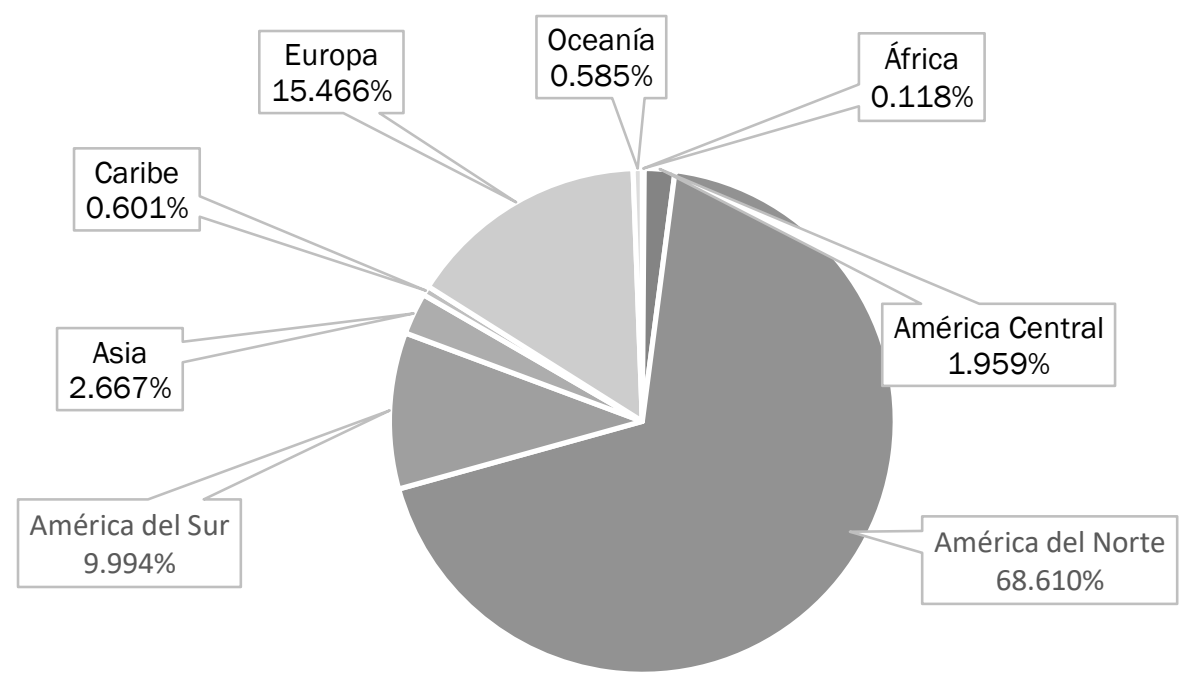

Fuente: Elaboración propia con base en datos de Secretaria de Gobernación (SEGOB 2019)

Gráfico 19. Composición de turismo por nacionalidad a México, 2012-2017

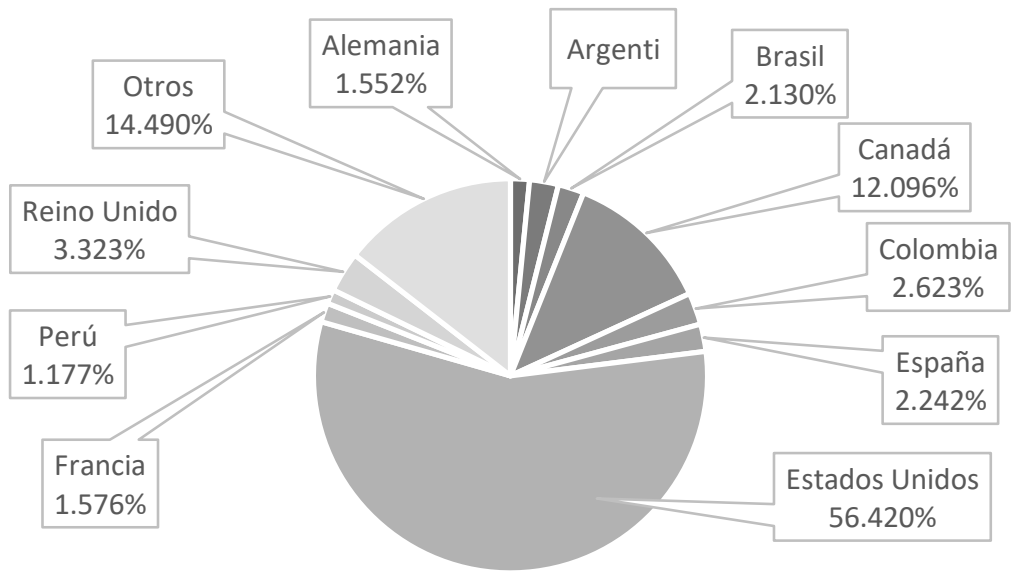

Fuente: Elaboración propia con información de Secretaria de Gobernación (SEGOB 2019)

El número de entradas totales de extranjeros es de 87335 553, de los cuales más de la mitad están explicadas por la región de América del Norte, 15.46\% por Europa y 9.99\% por América del Sur; estas tres regiones conforman el $99.05 \%$ de las entradas totales. A su vez las principales entradas de extranjeros por nacionalidad en México se conforman principalmente por norteamericanos con una participación del 56.42\%, los canadienses se ubican en segundo lugar, muy por debajo a las anteriores nacionalidades se ubica los extranjeros provenientes del Reino Unido, argentinos y colombianos con un porcentaje de $3.32 \% ; 2.62 \%$ y $2.24 \%$ respectivamente. 
Gráfico 20. Recepción de divisas por concepto de turismo en México, 2012-2017

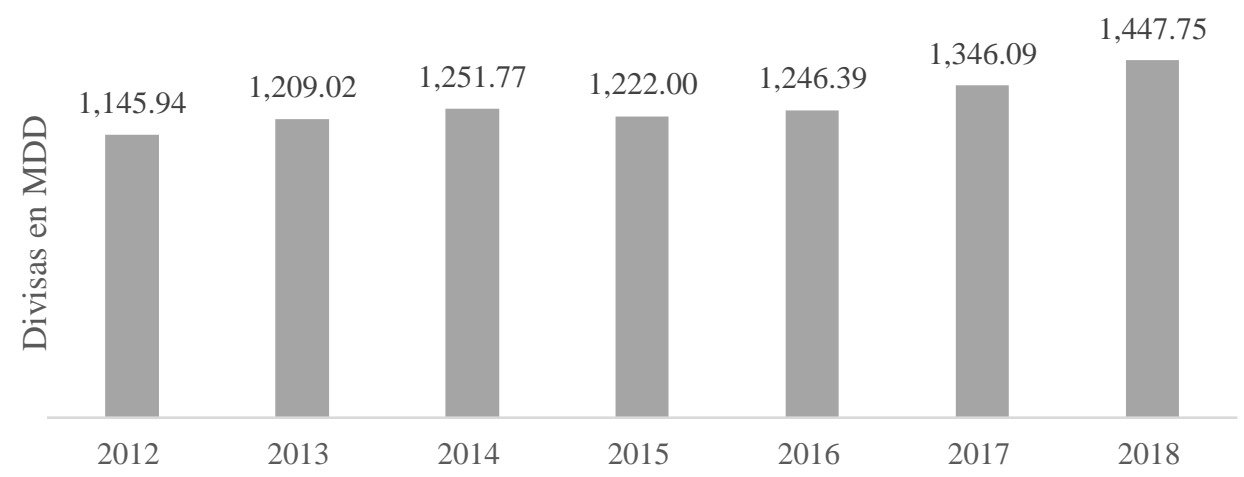

Fuente: Elaboración propia con base en datos de Organización Mundial del Turismo (UNWTO 2019)

Como se mencionó anteriormente México es uno de los principales receptores de turistas extranjeros a nivel mundial; en consecuencia, las divisas provenientes por turismo también son significativas. Es unas de las actividades con mayor entrada de divisas. Existen diversos factores que permiten pronosticar que, en un corto plazo, y como recientemente han señalado las autoridades federales, el turismo pueda llegar a desplazar a las remesas como uno de los más importantes generadores de divisas para el país (Pantoja 2019). México se posiciono entre el vigésimo tercer lugar y décimo cuarto lugar en la lista de los países con mayores ingresos provenientes de esta actividad. Existe una pequeña volatilidad en las divisas derivadas del turismo; sin embargo, el incremento ha sido notorio. De 2012 a 2017 los ingresos monetarios por turismo incrementaron 301810 miles de millones de pesos, lo que significa un crecimiento promedio anual del 3.27\%.

Gráfico 21. Composición del gasto total por turismo en México, 2012-2017

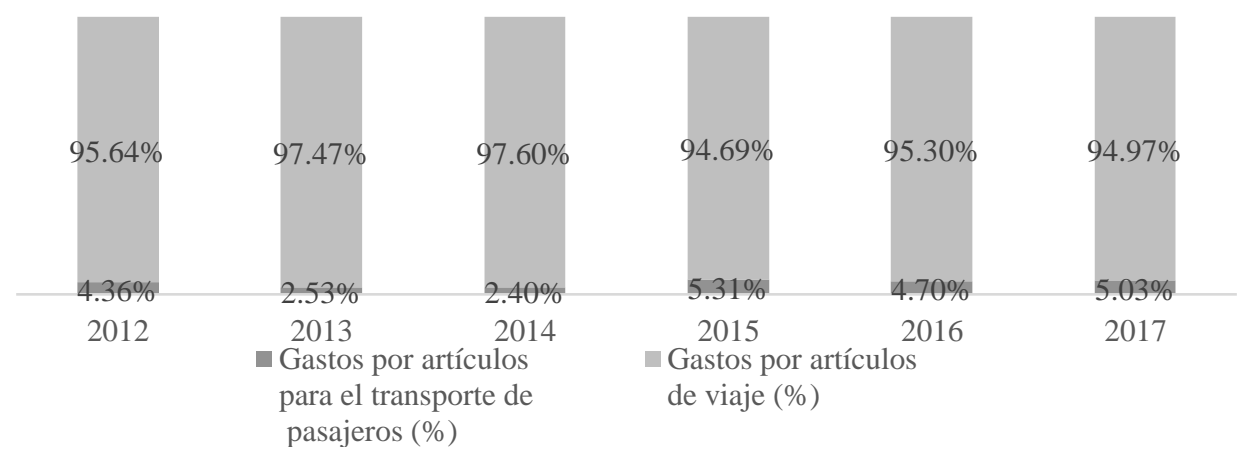

Fuente: Elaboración propia con base en datos de Banco Mundial (The World Bank Group 2019)

Como se muestra en el gráfico anterior el gasto total de turistas se divide en: gastos por artículos para el transporte de pasajeros ${ }^{1}$ y gasto por artículos de viaje ${ }^{2}$. De 2012 a 2017 el gasto en artículos de viaje superó el 95\% de los gastos totales, en 2013 y 2014 este

\footnotetext{
${ }^{1}$ Son los gastos incurridos por los visitantes internacionales que proceden del exterior en concepto de todos los servicios de transporte internacional provistos por transportistas residentes. También se incluyen los servicios de pasajeros prestados dentro de una economía por transportistas no residentes.

${ }^{2}$ Son los gastos realizados por los visitantes internacionales que proceden del exterior en la economía informante. Los bienes y servicios son comprados por el viajante o en su nombre, o provistos al viajante.
} 
porcentaje fue superior al 97\% el resto del periodo su participación disminuyó para llegar al 94.07\% del total en 2017. Para el caso del gasto por artículos de transporte de pasajeros podemos observar que este gasto representa como mínimo el 2.40\% y como máximo el $5.03 \%$ del gasto total.

Tabla 3. Composición del gasto total por turismo en México en millones de dólares, 2012-2017

\begin{tabular}{lcccccc}
\hline & 2012 & 2013 & 2014 & 2015 & 2016 & 2017 \\
\hline Gastos totales (A) & $13,320,000,000$ & $14,311,000,000$ & $16,606,000,000$ & $18,729,000,000$ & $20,619,000,000$ & $22,467,000,000$ \\
$\begin{array}{l}\text { Entradas de } \\
\text { extranjeros (B) }\end{array}$ & $10,826,326.00$ & $11,790,862.00$ & $12,958,514.00$ & $14,676,872.00$ & $16,192,687.00$ & $17,890,272.00$ \\
$\begin{array}{l}\text { Gastos personales } \\
\text { (B/A) }\end{array}$ & $1,230.33$ & $1,213.74$ & $1,281.47$ & $1,276.09$ & $1,273.35$ & $1,255.82$ \\
\hline
\end{tabular}

Fuente: Elaboración propia con base en datos de Banco Mundial (The World Bank Group 2019)

De 2012 a 2017 los gastos totales realizados por turistas extranjeros presentaron una tasa de crecimiento promedio anual de $11.02 \%$, esto significa que crecieron más que el sector y que el número de llegadas. No obstante, a lo largo del periodo de estudio el gasto personal se ha mantenido más o menos estable, esto se reflejó en su escaso aumento de 25.53 dólares, al mismo tiempo la tasa promedio de crecimiento de esta variable ha sido de solo $0.41 \%$. Lo que significa que el número de entradas de extranjeros no provoca que estos gasten más. Según la Organización Mundial de Turismo, México ocupa la cuadragésima posición en el gasto personal. Esto se ha convertido en un gran reto para el sector, expertos y empresarios interesados en este sector mencionan que se debe ponerse atención a la expansión del gasto promedio del turista extranjero sin descuidar el número de viajeros que se internan en México. La potencialidad turística de un país no se mide por el número de turistas recibidos, sino por las divisas captadas, en especial el gasto per cápita (Informador 2019).

\section{Perú}

Al analizar el sector turístico en Perú encontramos que existen otros sectores que aportan mayor porcentaje en el PIB nacional de Perú; por encima de este sector se encuentra: i) la manufactura; ii) extracción de petróleo, gas, minerales; iii) comercio; iv) construcción; v) agricultura, ganadería, casa y silvicultura; vi) electricidad, gas y agua; y vii) transporte, almacenamiento, correo y mensajería. No obstante, su participación se ha mantenido estable; (World Tourism Organization 2018 ) el aporte del PIB turístico ha aumentado del 2011 al 2015 de 3,6\% al 3,9\% (Ministerio de Comercio Exterior y Turismo 2016); del mismo modo, se estima que el impacto directo del turismo aumentará 4.5\% en el 2018 y $4.7 \%$ en los próximos diez años, hasta lograr US $\$ 13,403$ millones en divisas y el 4.2\% del PIB. En tanto, el aporte total crecerá a una tasa anual de $4.5 \%$ y sumará US $\$ 33,968$ millones en el 2028 (10.6\% del PIB).

Así mismo se estimado que aporta 1.1 millones de empleos directos e indirectos relacionado principalmente a restaurantes, servicios financieros, entretenimiento, transportes y agencias de viajes; entre otros. Con un ingreso de divisas de 4151 millones de dólares en 2015 y con incremento de 47.5\% entre el 2011 y 2016 el turismo se ha convertido en la segunda actividad con mayor ingreso de divisas. En 2010 Perú fue el décimo quinto país con mayor ingreso por concento de turismo internacional de América y el cuarto de América del Sur; encontrándose por detrás de Brasil, Colombia y Argentina 
(World Tourism Organization 2018 ). Entre 2010 y 2016 el ingreso por turismo internacional en Perú creció a una tasa promedio anual de 1.16\%, en el próximo continente observaremos que el turismo en este país está experimentando una continua contracción.

A pesar de sus grandes riquezas naturales y culturales, Perú no está dentro de los grandes del sector. Por el contrario, solo recibe el $0.3 \%$ del turismo mundial y el 3.5\% del turismo en Latinoamérica (Peñaranda Castañeda 2018); en 2016 se ubicó en el duodécimo lugar por número de visitantes extranjeros en América y el cuarto lugar en América del Sur; pero, como veremos varios indicadores comienzan a contraerse.

Gráfico 22. PIB turístico como porcentaje del PIB total de Perú, 2012-2017

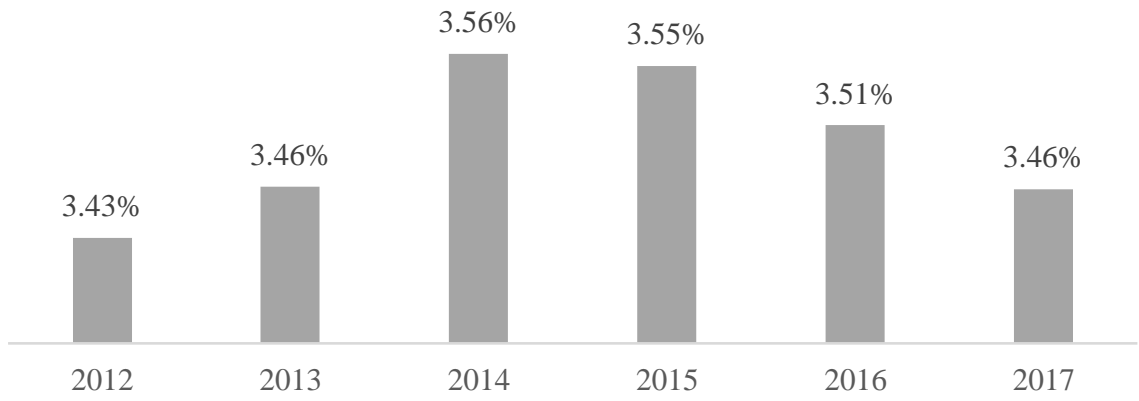

Fuente: Elaboración propia con base en datos de Instituto Nacional de Estadística e Informática (INEI 2019)

Por encima del turismo existe otros sectores que son más importantes para la economía peruana y que cuentan con una participación dentro del PIB nacional hasta de dos dígitos; para el caso de turismo, como se observa en la gráfica 4.1 su participación como porcentaje del PIB Total varía entre el 3.43\% y 3.56\%; de 2012 a 2014 existe un incremento continuo; sin embargo, desde 2015 decae.

Gráfico 23. Variación (\%) del PIB turístico en Perú, 2012-2017

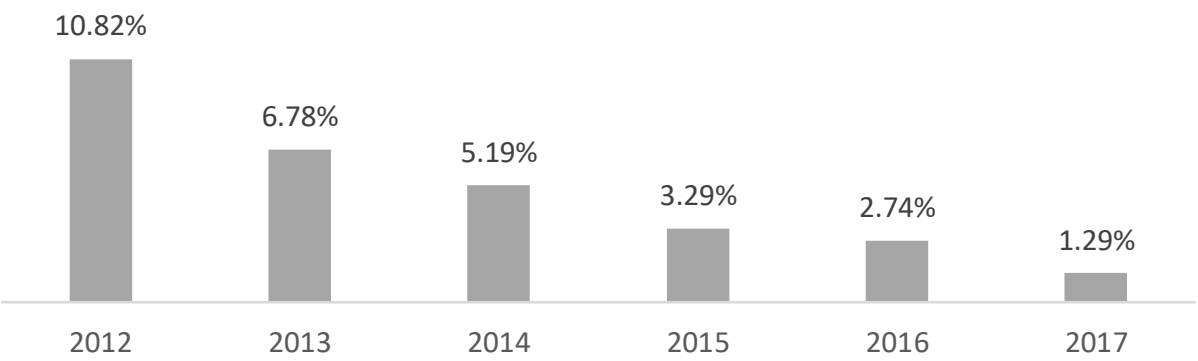

Fuente: Elaboración propia con base en datos de Instituto Nacional de Estadística e Informática (INEI 2019)

Como se ha mencionado anteriormente el turismo no es uno de los sectores más importantes de la economía peruana, en este sentido podemos observar como el crecimiento de este sector ha presentado continuas desaceleraciones. La mayor variación del PIB turístico se presentó en 2012; a partir de ese año la variación comenzó a disminuir entre un año y otro, hasta llegar a su crecimiento más bajo en 2017 con una tasa del 
1.29\%. No obstante, es importante recordar que, a pesar de bajo crecimiento del PIB turístico, los valores absolutos continúan siendo positivos. Así, por ejemplo, de 2012 a 2013 el PIB turístico creció 910000 de soles; de 2016 a 2017 esta cifra fue de solo 623000 soles.

Gráfico 24. Número de arribos a Perú por concepto de turismo, 2012-2017

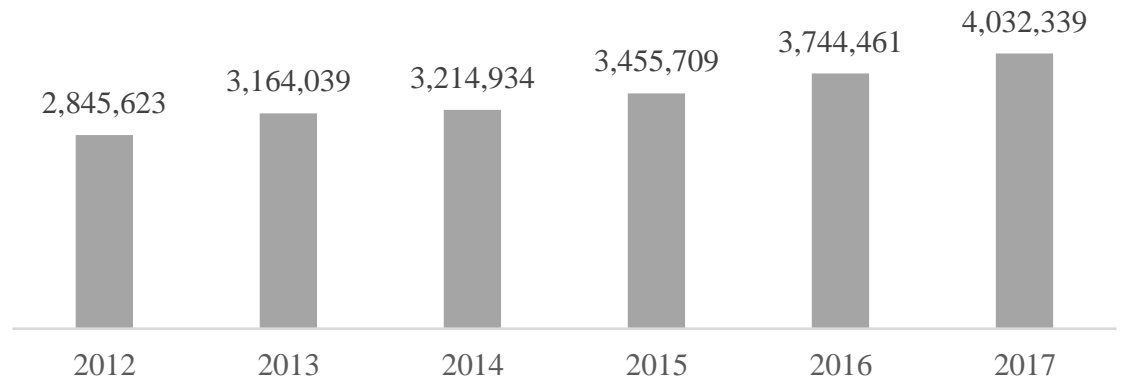

Fuente: Elaboración propia con base en datos de Ministerio de Comercio Exterior y Turismo (MINCETUR 2019)

De 2012 a 2017 Perú experimentó un incremento de 1571510 turistas extranjeros que se traduce en una tasa de 41.8\%; al mismo tiempo el incremento de estas visitas proporciona una tasa anual promedio del 9.2\%. Con un aumento de 319316 nuevas visitas de extranjeros el 2013 fue el año que presentó el mayor crecimiento; por el contrario, con un incremento del 1.54\% de visitas, 2014 es el año con menor aumento en visitas de turistas extranjeros.

Por el continuo incremento en el número de entradas de turistas extranjeros Perú ha sufrido un avance dentro del Ranking del Barómetro del Word Tourism Organization; en 2016 fue el octavo país de América y el cuarto de América del Sur más visitado; en 2017 se colocó en la séptima posición de los países más visitados de América y continuó siendo el cuarto país más visitado de América del Sur.

Gráfico 25. Participación (\%) en el ingreso de extranjeros a Perú, 2012-2017

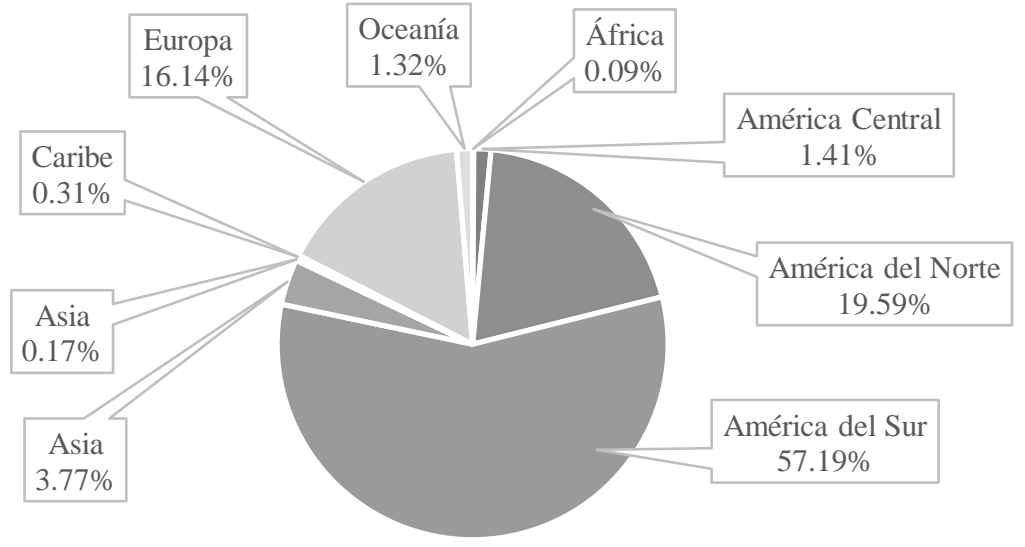

Fuente: Elaboración propia con base en datos de Ministerio de Comercio Exterior y Turismo (MINCETUR 2019) 
Gráfico 26. Participación (\%) en el ingreso de extranjeros a Perú por nacionalidad, 2012-2017

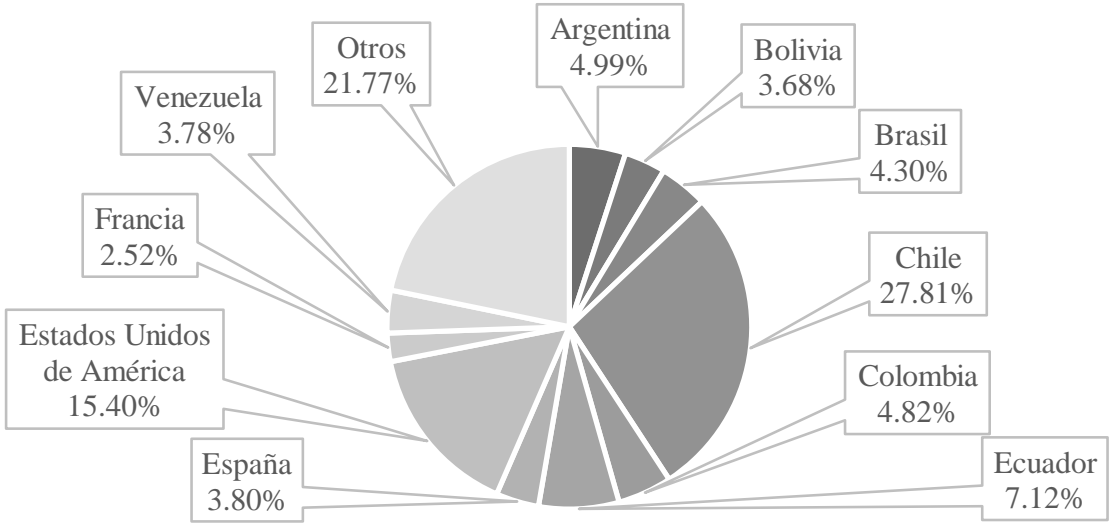

Fuente: Elaboración propia con base en datos de Ministerio de Comercio Exterior y Turismo (MINCETUR 2019)

Mas de la mitad de las visitadas extranjeras están explicadas por los turistas que provienen de América del Sur; con una participación del 19.59\% América del Norte es la segunda región que aporta mayor cantidad de turistas en Perú; en tercera posición por participación son los turistas provenientes de Asia. La principal nacionalidad de los extranjeros que visitan Perú son chilenos; tienen una participación del 27.82\%; aunque América del Sur tiene una amplia participación en el turismo de Perú, los estadunidenses conforma la segunda nacionalidad con mayor visitas a este país; según un informe de MINCETUR; Perú es el tercer destino de los estadunidense, y presentan un incremento anual promedio de 5\% (PROMERÚ 2017); con una participación del 7.12\% los ecuatorianos son la tercera nacionalidad con mayores visitas turísticas.

Gráfico 27. Divisas provenientes del turismo en Perú, 2012-2017

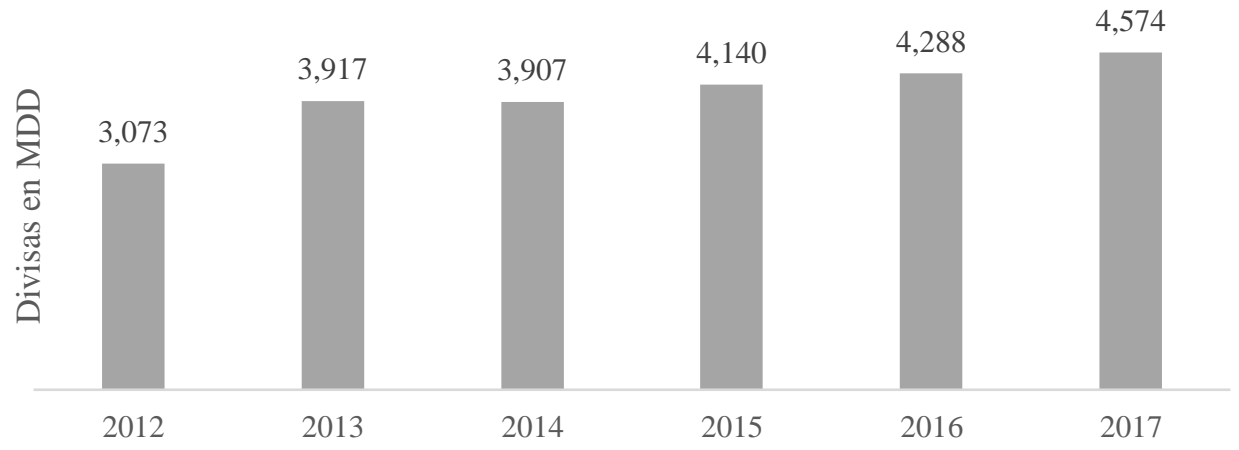

Fuente: Elaboración propia con base en datos de Ministerio de Comercio Exterior y Turismo (MINCETUR 2019)

El turismo receptivo en Perú es importante pues constituye una fuente significativa de divisas que contribuye a reducir el déficit estructural en la cuenta corriente de la balanza de pagos. Las divisas obtenidas representan aproximadamente 2\% del PIB y $7 \%$ de las Reservas Internacionales (Peñaranda Castañeda 2018). En 2017 Perú fue el décimo quinto país de América y el quinto de América Latina con mayor cantidad de ingresos por concepto de turismo, encontrándose por detrás de países como Brasil, Argentina, Chile y Colombia; sin embargo; existe un retroceso de este indicador; en 2010 Perú ocupaba el noveno país de América y el cuarto de América Latina del ranking de ingresos 
provenientes del turismo (World Tourism Organization 2018 ). De 2012 a 2017 las divisas por turismo en Perú incrementaron 1501 dólares que da una tasa acumulada del 48.4\%; al mismo tiempo, el mismo periodo da una tasa promedio anual de 8.28\%. Durante 2013 se obtuvieron 3917 dólares de divisas por turismo lo que representa un crecimiento de 27.47\%; en 2014 hubo una reducción en las divisas del 0.26\%; no obstante, los tres años consecutivos presentaron tasas de crecimiento de 5.96\%; 3.57\% y 6.67\%. Así que podemos decir, que a pesar de retroceso que ha tenido regionalmente el turismo en Perú, este sector sigue siendo importante por la cantidad de divisas que atrae.

Gráfico 28 Composición (\%) del gasto total por concepto de turismo en Perú, 2012-2017

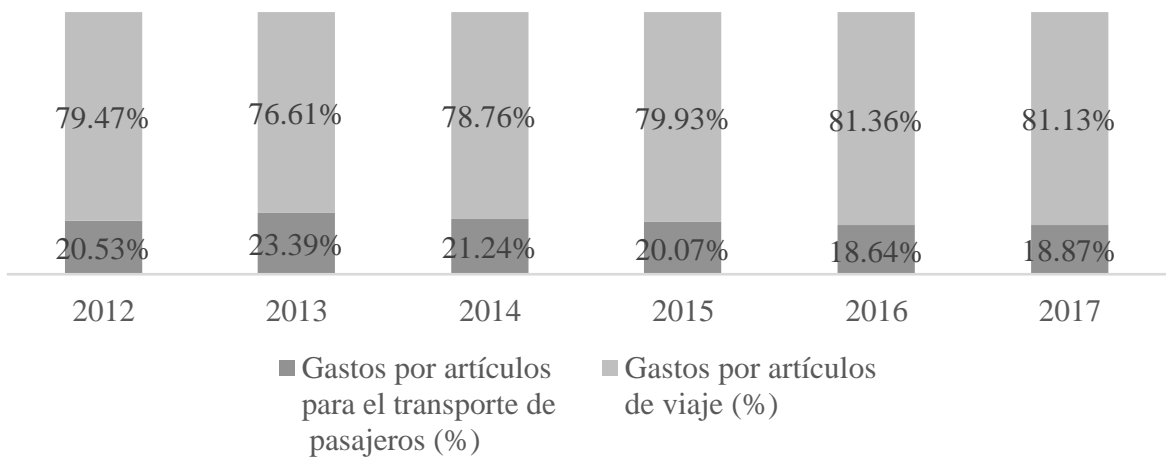

Fuente: Elaboración propia con base en datos de Banco Mundial (The World Bank Group 2019)

La composición de los gastos totales refleja que a lo largo del periodo el porcentaje del gasto en artículos por el transporte de pasajeros ha disminuido en contraste al incremento que ha tenido del $79.97 \%$ al $81.13 \%$ los gasto por artículos de viaje; esto es resultado en gran medida al abaratamiento de los costos del transporte orientado al turismo.

Tabla 4 Composición del gasto total por concepto de turismo en Perú en millones de dólares, 2012-2017

\begin{tabular}{|c|c|c|c|c|c|c|}
\hline & 2012 & 2013 & 2014 & 2015 & 2016 & 2017 \\
\hline Gastos totales (A) & $3,074,000,000$ & $3,916,000,000$ & $3,907,000,000$ & $4,140,000,000$ & $4,303,000,000$ & $4,573,000,000$ \\
\hline $\begin{array}{l}\text { Entradas de } \\
\text { extranjeros (B) }\end{array}$ & $2,835,770$ & $3,155,086$ & $3,203,612$ & $3,444,466$ & $3,732,625$ & $4,021,918$ \\
\hline $\begin{array}{l}\text { Gastos personales } \\
\text { (A/B) }\end{array}$ & $1,084.01$ & $1,241.17$ & $1,219.56$ & $1,201.93$ & $1,152.81$ & $1,137.02$ \\
\hline
\end{tabular}

Fuente: Elaboración propia con base en datos de Banco Mundial (The World Bank Group 2019)

Como resultado del aumento de las divisas obtenidas del turismo; los gastos totales también han aumentado; este aumento es equivalente a 1499000000 dólares y representa una tasa acumulada del $48.76 \%$ y una tasa promedio anual de $8.27 \%$ (tasa acumulada y tasa promedio anual parecida a la de los ingresos por turismo); a pesar de que los gastos personales han disminuido de 2013 a 2017; el resultado final respecto al inicio del periodo sigue siendo un incremento de 53.02 dólares.

\section{EFECTO DE LA ALIANZA DEL PACIFICO EN EL SECTOR TURÍSTICO DE LOS PAÍSES SOCIOS}




\section{Periodo previo a la conformación de la Alianza del Pacífico}

De los países que integran hoy la Alianza del Pacifico, México destaca en captación de turismo internacional, mostrando un ligero aumento en el arribo de turistas del año 2009 al 2011. Sin embargo, para el año 2012 el arribo de turistas se mantiene relativamente constante. En lo relacionado a Chile y Perú, destaca un crecimiento atribuible al análisis de las políticas de desarrollo para la implementación de una estrategia de turismo. A diferencia Colombia, muestra una serie de altibajos en arribo de turistas del 2009 al 2012 explicado por la inestabilidad política y social del periodo en cuestión.

Gráfico 29. Número de arribos a los países miembros de la Alianza del Pacífico

Turismo internacional, número de arribos a Chile, Colombia, México y Perú en el periodo 2009-2012

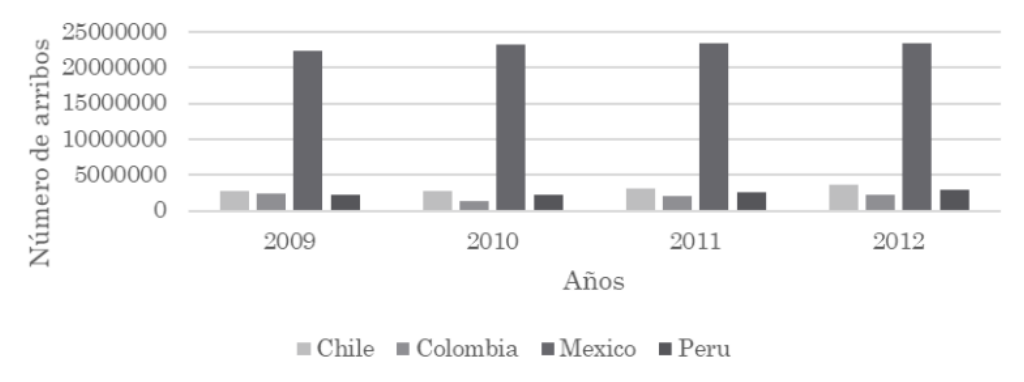

Fuente: Elaboración propia con base en datos del Banco Mundial (The World Bank Group 2019).

Otro punto importante a considerar es cómo ha evolucionado el porcentaje de participación de los ingresos por turismo al total de exportaciones. Los ingresos por turismo internacional son gastos de los visitantes internacionales entrantes, incluidos los pagos a los transportistas nacionales para el transporte internacional. ${ }^{3}$ Su participación en las exportaciones se calcula como una relación a las exportaciones de bienes y servicios, que comprenden todas las transacciones entre residentes de un país y el resto del mundo que involucran un cambio de propiedad de residentes a no residentes de mercancías generales, bienes enviados para su procesamiento y reparaciones, oro no monetario, y servicios (WBG 2019)

\footnotetext{
${ }^{3}$ Estos recibos incluyen cualquier otro pago anticipado realizado por bienes o servicios recibidos en el país de destino. También pueden incluir recibos de los visitantes del mismo día, excepto cuando estos son lo suficientemente importantes como para justificar la clasificación por separado. Para algunos países no incluyen recibos por artículos de transporte de pasajeros. (WBG 2019)
} 
Gráfico 30. Participación (\%) de los ingresos por turismo en total de las exportaciones

Porcentaje de los ingresos por turismo al total de las exportaciones.

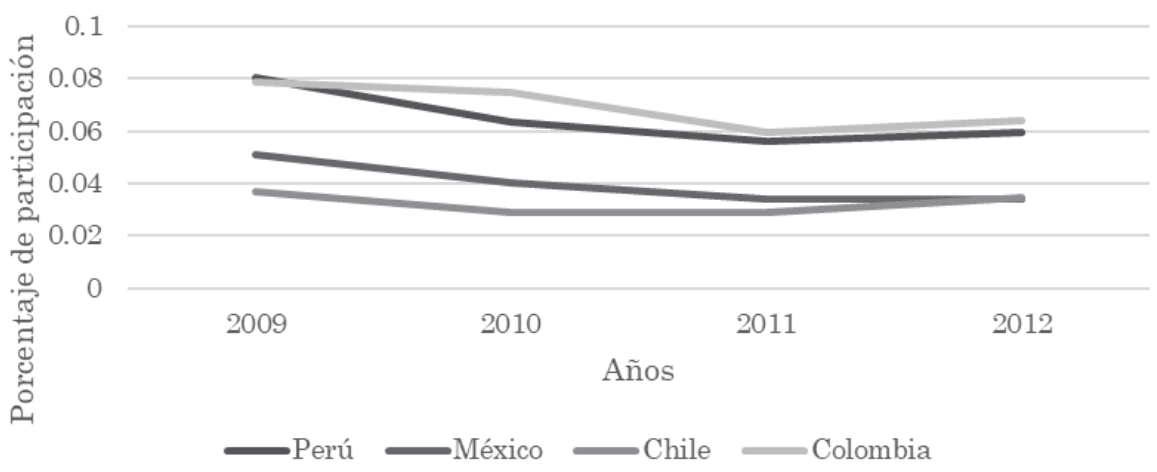

Fuente: Elaboración propia con base en datos del Banco Mundial (The World Bank Group 2019)

En este sentido desde el año 2009 al 2012 podemos notar un comportamiento decreciente en el porcentaje de participación de Perú, Colombia y México, sin embargo, en el caso de Chile se aprecian un comportamiento creciente que continua presente en años posteriores. ${ }^{4}$

\section{Efecto de la Alianza del Pacífico en el sector turístico de los países socios}

En el sector de servicios, específicamente en el área de Turismo, se ha gozado de una evolución constante desde el año 2012 al 2017, influenciada principalmente por el Acuerdo de Cooperación en Materia de Turismo (Alianza del Pacífico 2019) dada la suscripción formal de la AP, en dicho acuerdo se da pauta a la conformación del grupo técnico de turismo con el objetivo de trabajar en proyectos orientados al fortalecimiento de las relaciones en materia de Turismo que conlleven al mayor flujo de turistas entre los participantes de la Alianza. Con la conformación del grupo técnico, llega la primera reunión efectuada por el mismo con sede en la ciudad de Chile en mayo del 2013 (AP 2015), en dicha reunión se acordó trabajar en áreas prioritarias como el libre intercambio de productos turísticos, así como brindar servicios de calidad para generar experiencias exitosas y la intención de lograr el apoyo reciproco de organismos multilaterales como la Organización mundial del Turismo.

Con las cuatro economías trabajando en conjunto al interior de la AP se observa que el comportamiento a partir del año 2012 se diferencia de forma positiva del periodo anterior a la Alianza, por un lado, México se encuentra en primer lugar en el arribo de turistas con un promedio anual de 28,044,667 millones de visitantes, seguido esta Chile con 4,007,889 y en tercer lugar se posiciona Perú y Colombia con 3,054,889 y 2,581,557 respectivamente. Al observar el caso de Colombia se observar un incremento año con año de manera constante hasta el 2017 donde logra superar a Perú en captación de turistas extranjeros. ${ }^{5}$ Este aspecto es importante dada la apertura que ha tenido en los últimos años gracias a los acuerdos de paz, formalizados con la firma del Acuerdo de Habana entre el gobierno colombiano y las FARC-EP, de esta forma al reducirse el

${ }^{4}$ Nótese en grafico 3

${ }^{5}$ Nótese en gráfico 4. 
presupuesto militar el gobierno cuenta con más recursos para destinarse en el sector turismo (Gómez Suárez 2014).

Gráfico 31. Número de arribos a los países socios de la Alianza del Pacífico, 2012-2017

Turismo internacional, número de llegadas a los paises de la AP

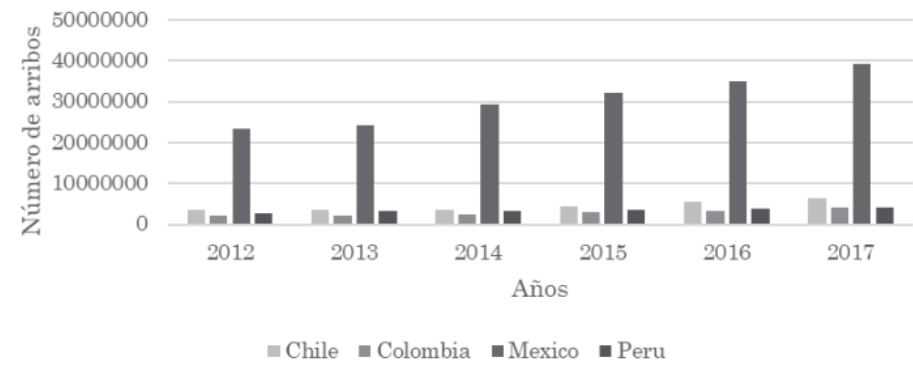

Fuente: Elaboración propia con base en datos de Banco Mundial (The World Bank Group 2019)

Los efectos de la implementación de mecanismos de integración que permitan promocionar el turismo dentro de los mismos, así como unir fuerzas para su promoción en el exterior trae como consecuencia un aumento en el porcentaje de participación del turismo al total de las exportaciones, en este sentido, a partir del 2012 las tendencias de comportamiento a la baja por parte de Perú, México y Colombia se modifican hacían una tendencia positiva, en los cuatro países socios.

Gráfico 32. Participación (\%) de los ingresos por turismo al total de las exportaciones.

Porcentaje de los ingresos por turismo al total de las exportaciones.

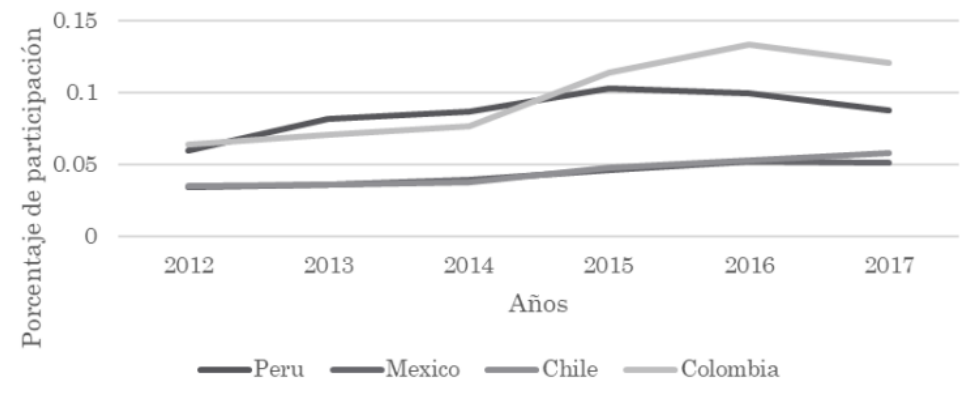

Fuente: Elaboración propia con datos de (The World Bank Group 2019)

En efecto el turismo en los países analizados ha mostrado un avance creciente y positivo del año 2012 en adelante, sin embargo, al efectuar una comparación de los dos periodos, respecto al flujo de salidas de Colombia a los países miembros de la AP, es más claro el cambio positivo, en el año a partir de cual se consolida la Alianza del Pacífico. Luego entonces, en el primer periodo, antes de la conformación de la Alianza, el turismo de Colombia a los países miembros de la Alianza crecía sin aumentos significativos, y prácticamente a la par, específicamente a México y Perú, sin embargo, al consolidarse la Alianza en el año 2012 existe un incremento en el turismo dirigido a México, en promedio, 
durante el periodo analizado se registraron 232,133 de partidas con destino a dicho país, ${ }^{6}$ por su parte el turismo dirigido a Perú y Chile continuaron creciendo de forma constante.

Gráfico 33. No. de viajeros procedentes de Colombia a los Países socios de la Alianza del Pacífico, 2009-2017

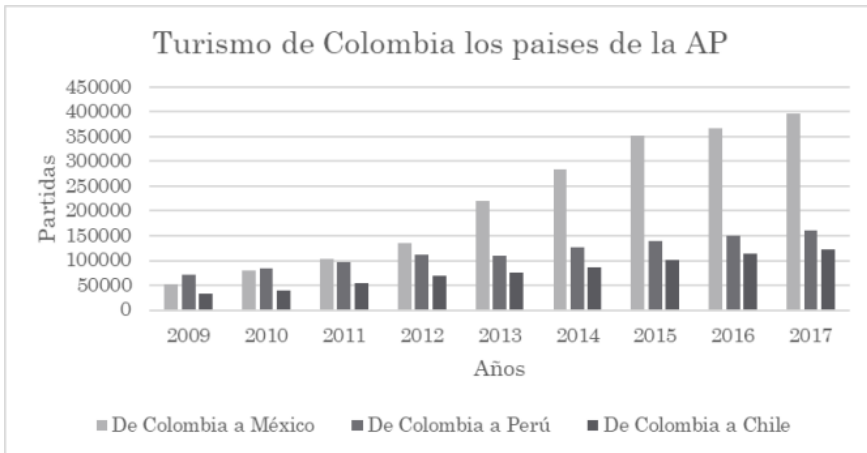

Fuente: Elaboración propia con base en datos del Ministerio de Comercio, Industria y Turismo (OEE- MINCIT 2019)

Si se compara Chile, México y Perú (Gráfico 37), se observa que en general el comportamiento del turismo bilateral entre los países miembros de la Alianza ha sido creciente durante el periodo de análisis, haye casos muy marcados en volumen como el turismo de Chile a Perú que aportó un promedio anual de 869,973 visitantes al país receptor. Por el lado opuesto, esta la relación de las partidas de México a Chile con un promedio anual de 39,637 arribos al país receptor. ${ }^{7}$

Gráfico 34. Turismo bilateral entre países socios de la Alianza del Pacífico, 2009-2018

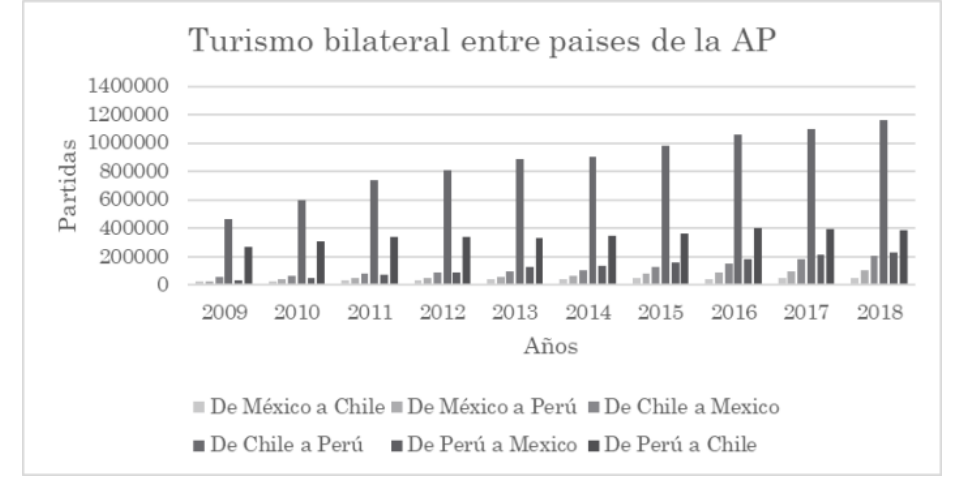

Fuente: Elaboración propia con datos recabados del Ministerio de Comercio, Industria y Turismo CONCLUSIONES (OEE- MINCIT 2019)

Se ha mostrado que a lo largo del periodo de 2009 al 2017, los flujos en el turismo muestran una propensión a viajar fuera del entorno habitual y en consecuencia una tendencia de crecimiento que se mantiene. En los cuatro países que integran la AP, dicha situación no era tan evidente en los años previos a la firma del acuerdo, donde la tendencia de crecimiento era moderada, aunque en ritmos diferentes para cada uno de ellos, siendo notorio el volumen de turistas en México respecto de los demás. Tanto Chile

${ }^{6}$ Promedio calculado en base a los datos anuales de turismo emisor de Colombia a los países de la AP. (OEE- MINCIT 2019)

7 Nótese en el gráfico 8 
como Perú tuvieron un crecimiento constante a diferencia de Colombia que muestra una serie de altibajos en el arribo de turistas del 2009 al 2012.

Con la firma de la Alianza del Pacifico (en 2012) se aprecian cambios importantes en la dinámica turística de los países miembros. Uno de los principales logros de la Alianza del Pacifico para promover el turismo en los países socios es la exoneración de visas de turismo y negocios para nacionales y extranjeros residentes permanentes de los países miembros, dicha medida se implementó en su totalidad a partir del 2016 y funge como una pieza elemental para alcanzar la libre circulación de personas al interior de la alianza.

Se ha mostrado la importancia económica que tiene para los países en desarrollo la creación de mecanismos de integración que contribuya al desarrollo económico de los mismos, en este sentido la promoción en materia de turismo efectuada por la Alianza del Pacífico al interior, así como al exterior, permitió a los países miembros acrecentar sus ingresos a partir de la creación de está hasta el presente. De la misma forma se encontró que los efectos positivos de la AP abarcan una serie de consecuencias positivas para las economías en cuestión, principalmente en la que a creación de empleos se refiere.

Es importante no dejar de considerar las medidas internas que fortalecen en conjunto a la Alianza del Pacifico. Tal es el caso de Chile, país en el cual el avance de políticas ha brindado resultados significativos, observados principalmente por los datos en materia de arribo de turistas que mostraron un crecimiento constante al grado de duplicar el volumen de captado al 2017. Por otro lado, esta el caso de Perú el cual no mostro un avance significativo en la captación de turismo extranjero, sin embargo, el porcentaje que representa al total de las exportaciones es mayor en comparación con México o Chile.

En México es interesante destacar los resultados del ranking de competencia turística del FMl en el cual dicho país figura en el lugar número uno en materia de recursos naturales, destacando principalmente por el desarrollo de actividades turísticas al aire libre y su rico capital natural, sin embargo, referente a seguridad y protección México figura en los lugares 136 en materia de costos comerciales del crimen y la violencia, así como en el lugar 138 referente a la fiabilidad de los servicios policiales. Estos son puntos importantes de análisis para las agendas públicas, dado el gran potencial de México como generador de divisas en materia de turismo.

Finalmente, pero menos importante, se encuentra el caso de Colombia, cuyo ejemplo de estabilidad política y social demostrado en los últimos años ha traído consigo un aumento sustancial en el sector turístico reforzado en gran medida por la promoción interna y externa por medio de la Alianza del Pacifico. Actualmente dicho país enfrenta grandes retos como la mejora en infraestructura terrestre, portuaria y aérea, así como mejorar la infraestructura de los servicios turísticos. Sin embargo, como se vio, el aumento del turismo sigue creciendo año con año en materia de arribo de turistas, así como los ingresos como porcentaje del PIB.

Debe destacarse es como en la medida que uno de los objetivos de la AP es la promoción del turismo entre sus países, es evidente un turismo bilateral creciente. Sin embargo, sobresale el hecho del incremento del turismo chileno a Perú y de Colombia a México, no es la misma relación de turistas peruanos a Colombia y viceversa. En este sentido, se 
podría señalar que por ahora a quienes más ha servido el acuerdo de la Alianza del Pacifico en la recepción de turistas es a México y Perú y, en menor medida a Colombia y Chile.

Son siete años del acuerdo y si bien se han logrado cosas importantes en todos los temas que lo componen son muchos los retos que tiene que afrontar y uno de ellos es en el campo turístico. Un primer aspecto, pasa por fortalecer el sector turístico en los países, se suma la necesidad de favorecer una mayor seguridad turística, mejores ofertas, así como la innovación y el desarrollo de emprendimientos. Pese a todo lo que se ha logrado persisten retos importantes al interior de la Alianza del Pacifico principalmente en lo que respecta al tema de la seguridad turística, el cambio climático, innovación y emprendimientos en turismo.

\section{REFERENCIAS}

Albertini, Camila. «¿Cuánto gastan los turista que visitan Chile?» Publimetro, 10 de enero de 2018.

Alianza del Pacífico. Alianza del Pacífico. El poder de la integración. 2019. (último acceso: 14 de 06 de 2019). https://alianzapacifico.net/grupo-tecnico-de-turismo/

AP. «Alianza pacífico.» 20 de 01 de 2015. https://alianzapacifico.net/grupo-tecnico-de-turismo/ (último acceso: 08 de 06 de 2019).

Banco Central de Chile. 2019. https://si3.bcentral.cl/Siete/secure/cuadros/home.aspx?ldioma=es-ES

Carranza Jiménez, Diego Camilo. «Record en llegada de turistas extranjeros a Colombia en 2017.» 100 YEARS, 2 de Febrero de 2018.

CITUR. Centro de Información turística de Colombia. 2019. (último acceso: 25 de 03 de 2020). http://www.citur.gov.co/estadisticas

DANE. Departamento Administrativo Nacional de Estadístico. 15 de 12 de 2019. (último acceso: 23 de 03 de 2020). https://www.dane.gov.co/

Díaz, Fernanda Villalobos. «El turismo como potencial para el crecimiento de Chile: ¿Estamos preparados?» emol. social, 6 de Septiembre de 2016.

Espinoza, Alejandra. «Una década y tres gobiernos: momentos para recordar del turismo en México.» Expansión, 20 de diciembre de 2019.

Excelsior. «Aventaja crecimiento del turismo mexicano al promedio de la economía.» Cámara de Comercio. Servicios y Turismo, 2016 : http://www.ccmexico.com.mx/blog/hoticias/aventajacrecimiento-del-turismo-mexicano-al-promedio-de-la-economia.html

Gómez Suárez, Diego Francisco. «Repositorio de la Universidad Militar de Nueva Granada.» 28 de 10 de 2014. (último acceso: 14 de 06 de 2019). https://repository.unimilitar.edu.co/bitstream/handle/10654/12934/Debilidades\%20de\%20Colo mbia\%20frente\%20a\%20la\%20Alianza\%20de|\%20Pacifico.\%20.pdf?sequence=18isAllowed=y

INEGI. Instituto Nacional de Estadística y Geografía. 24 de 12 de 2019. (último acceso: 25 de 03 de 2020). https://www.inegi.org.mx/

INEI. «Instituto Nacional de Estadística e informática.» Cuentas nacionales. 21 de 12 de 2019. (último acceso: 26 de 03 de 2020). https://www.inei.gob.pe/

Informador. «Los turistas extranjeros que más gastan en México.» Informador, 7 de Febrero de 2019. 
MINCETUR. «Ministerio de Comercio Exterior y Turismo.» 15 de 12 de 2019. (último acceso: 24 de 03 de 2020). https://www.gob.pe/mincetur

MINCIT. Ministerio de Comercio, Industria y Turismo. 2017. (último acceso: 17 de 06 de 2019). http://www. mincit.gov.co/

Ministerio de Comercio Exterior y Turismo. "Dirección General de Investigación y Estudios en Turismo y Artesanía-DGIETA.» Medición Económica del Turismo. 2016. (último acceso: 03 de 2020).

OEE- MINCIT. Ministerio de Comercio, Industria y Turismo. Colombia: Migración Colombia, 2019.

Pantoja, Carlos. «Turismo, una fuente inagotable de divisas para México.» Deloitte, 2019

Albertini, Camila. «¿Cuánto gastan los turista que visitan Chile?» Publimetro, 10 de enero de 2018.

Alianza del Pacífico. Alianza del Pacífico. El poder de la integración. 2019. (último acceso: 14 de 06 de 2019). https://alianzapacifico.net/grupo-tecnico-de-turismo/

AP. «Alianza pacífico.» 20 de 01 de 2015. (último acceso: 08 de 06 de 2019). https://alianzapacifico.net/grupo-tecnico-de-turismo/

Banco Central de Chile. 2019. https://si3.bcentral.cl/Siete/secure/cuadros/home.aspx?ldioma=es-ES

Carranza Jiménez, Diego Camilo. «Record en llegada de turistas extranjeros a Colombia en 2017.» 100 YEARS, 2 de Febrero de 2018.

CITUR. Centro de Información turística de Colombia. 2019. (último acceso: 25 de 03 de 2020). http://www.citur.gov.co/estadisticas

DANE. Departamento Administrativo Nacional de Estadístico. 15 de 12 de 2019. (último acceso: 23 de 03 de 2020). https://www.dane.gov.co/

Díaz, Fernanda Villalobos. «El turismo como potencial para el crecimiento de Chile: ¿Estamos preparados?» emol. social, 6 de Septiembre de 2016.

Espinoza, Alejandra. «Una década y tres gobiernos: momentos para recordar del turismo en México.» Expansión, 20 de diciembre de 2019.

Excelsior. «Aventaja crecimiento del turismo mexicano al promedio de la economía.» Cámara de Comercio. Servicios y Turismo, 2016: http://www.ccmexico.com.mx/blog/hoticias/aventajacrecimiento-del-turismo-mexicano-al-promedio-de-la-economia.html

Gómez Suárez, Diego Francisco. «Repositorio de la Universidad Militar de Nueva Granada.» 28 de 10 de 2014. (último acceso: 14 de 06 de 2019). https://repository.unimilitar.edu.co/bitstream/handle/10654/12934/Debilidades\%20de\%20Colo mbia\%20frente\%20a\%20la\%20Alianza\%20de|\%20Pacifico.\%20.pdf? sequence=18is Allowed=y

INEGI. Instituto Nacional de Estadística y Geografía. 24 de 12 de 2019. (último acceso: 25 de 03 de 2020). https://www.inegi.org.mx/

INEI. «Instituto Nacional de Estadística e informática.» Cuentas nacionales. 21 de 12 de 2019. (último acceso: 26 de 03 de 2020). https://www.inei.gob.pe/

Informador. «Los turistas extranjeros que más gastan en México.» Informador, 7 de Febrero de 2019.

MINCETUR. «Ministerio de Comercio Exterior y Turismo.» 15 de 12 de 2019. (último acceso: 24 de 03 de 2020). https://www.gob.pe/mincetur 
MINCIT. Ministerio de Comercio, Industria y Turismo. 2017. (último acceso: 17 de 06 de 2019). http://www.mincit.gov.co/

Ministerio de Comercio Exterior y Turismo. «Dirección General de Investigación y Estudios en Turismo y Artesanía-DGIETA.» Medición Económica del Turismo. 2016. (último acceso: 03 de 2020).

OEE- MINCIT. Ministerio de Comercio, Industria y Turismo. Colombia: Migración Colombia, 2019. Pantoja, Carlos. «Turismo, una fuente inagotable de divisas para México.» Deloitte, 2019.

Parcerisa, Christin. «Turismo en México, el sector que más aporta al producto interno bruto.» Forbes, 10 de septiembre de 2017.

Peñaranda Castañeda , César . «Sector turismo representa el 3.3\% del pib y genera 1.1 millones de emploep.» La Cámara, 2018: 16-18.

Pinto Molinares, Daniela . «El turismo crece más que la economía en Colombia: Consejo mundial.» El tiempo, 18 de Marzo de 2019.

Portafolio. «En seis años el PIB del turismo creció 24\%.» Portafolio, 08 de Marzo de 2018.

PROMERÚ. Top 3: Destinos sudamericanos de turistas estadounidenses. Lima: PROMPERÚ, 2017.

PROMPERÚ. Comisión de Promoción para la exportación y el Turismo. 2018. (último acceso: 18 de 06 de 2019). https://www.promperu.gob.pe/

Reuters. «El turismo en México crece 2.1\%.» Expansión, 16 de agosto de 2013: https://expansion.mx/economia/2013/08/16/turismo-en-mexico-crece-21

Santoro, Flavia. «La hora del turismo para Colombia.» La República, 31 de enero de 2019.

SEGOB. Secretaría de gobernación. 27 de 12 de 2019. (último acceso: 26 de 03 de 2020). http://portales.segob.gob.mx/es/PoliticaMigratoria/Cuadros MyH?Anual=2019\&Secc=1

SERNATUR. Servicio Nacional de turismo. 2019. (último acceso: 16 de 06 de 2019). https://www.sernatur.cl/

Servicio Nacional de Turismo. «Llegada de turista extranjero e ingresos de divisas baten récord durante 2017.» SENATUR, 9 de Enero de 2018.

—. «Llegada de turistas extranjeros alcanza récord en 2016: 5 millones 640 mil personas visitaron Chile.» SENATUR, 10 de enero de 2017.

The World Bank Group. World Development Indicators. 2019. (último acceso: 25 de 03 de 2020). https://databank. worldbank.org/data/reports.aspx? source=2\&series=ST.INT.RCPT.XP.ZS\#

- World Development Indicators. 2019. (Último acceso: 12 de 06 de 2019). https://databank.worldbank.org/data/reports.aspx? source=2\&series=ST.INT.RCPT.XP.ZS\#

UNWTO. Organización Mundial de Turismo. 2019. http://www2.unwto.org/es (último acceso: 17 de 06 de 2019).

WBG. World Bank Group. 2019. (Último acceso: 12 de 06 de 2019). https://datacatalog.worldbank.org/search? search api views fulltext op=AND\&query=Tourism \&f\%5B0\%5D=field wbddh country\%3A81\&sort by=search api relevance\&sort by=search api relevance\#

World Tourism Organization. «Panorama OMT del turismo internacional .» 2018. 